\title{
O conceito unitario do contrato de seguro $\left({ }^{1}\right)\left({ }^{2}\right)$
}

\author{
Tullio Ascarelli
}

\section{S U M A R I O}

1 - o problema dum conceito unitário do contrato de seguro. Posição da doutrina. 2 - A teoria da necessidade. Sua verdade e insuficiência. 3 - A teoria da emprêsa. Sua utilidade e insuficiência. $4-0$ seguro como contrato de indenisação mesmo na hipotese do seguro de vida. $5-A$ inestimabilidade dos bens pessoais. Exatidão, mas insuficiência desta observação. 6 - A doutrina geral do ressarcimento. 7 - Dano emergente. Lucro cessante. Vantagem esperada. 8 - Consequencias na questão probatoria Avaliação abstrata e concreta. 9 - Consequencias no problema do seguro. 10 - Os varios ramos de seguro em relação com o dano emergente: a) Seguro dos danos às coisas; b) Seguro nupcial; c) Seguro da responsabilidade civil. 11 - Em relação com o lucro cessante ou vantagem esperada: a) Seguros de acidentes; b) Seguros nos casos de morte; c) 0 seguro a favor de um terceiro beneficiario; d) Seguros sociais; e) 0 interesse nos seguros no caso de morte; f) 0 seguro no caso de vida; g) Ainda os seguros no caso de vida; h) A doutrina do interesse asseguravel nos seguros de pessoas; i) Ramos mistos. 12 - Importancia das conclusões obtidas: a) Seguros de acidentes; b) os seguros sociais;

(1) Circunstancias independentes da minha vontade impediram-me de completar este estudo com o aparato bibliografico que seria mister e que se destinaria, não tanto a promover uma especie de torneio de opiniōes, do qual o próprio autor sóe sair após naturalmente vencedor e que constitue a influencia não benefica que sobre nossa obra de juristas exerce nossa profissão de advogados, como a mostrar o elemento de verdade que frequentemente deriva das teorias opostas $e$ a colher $e$ indicar as varias afirmações que, nas teorias depois criticadas, contêm a indicação da solução aqui defendida.

$O$ progresso do pensamento, mesmo na ciencia juridica, não aparece atravez a contraposição polemica das varias opiniões, mas pelo seu sucessivo superamento, em formulas sempre mais largas que, atendendo as exigencias proprias de cada uma, satisfazem-nas e em seguida superam-nas. Esta, mesmo na ciencia juridica, é a unica via fecunda e é diante déla que qualquer solução não é sinão etapa que faz nascer novos problemas, exigindo novas soluções, instrumento de trabalho com o qual cada um contribue para uma obra coletiva.

(2) Traduzido pelo professor Ernesto Leme e pelo sr. Aristides Lobo.

(3) Catedratico de direito comercial da Universidade de Bolonha, Italia, e professor contratado pela Faculdade de Direito da Universidade de São Paulo. 
c) Diferencas entre seguro no caso de morte e no caso de sobrevivencia. 13 - Avaliação abstrata e avaliação concreta do dano: a) Limites da indenisação; b) Proporcionalidade; c) Pluralidade de seguros; d) Subrogação. 14 - Classificação dos ramos de seguro.

1 - O problema preliminar da teoria do seguro foi sempre o da possibilidade dum conceito unitario do contrato de seguro; o da unidade entre seguro de vida e seguro dos danos.

Estas duas formas de seguro juntam-se na lei e na consciencia comum como sub-especies de um unico genero (o genero, seguro). Todavia é dificil identificar os caracteres comuns que deveriam igualmente distinguí-los, tanto que não são raros agora os que renunciaram francamente à tentativa de conceber um conceito unico de seguro.

Efetivamente, enquanto o seguro dos danos aparece como um contrato de indenisação e encontra substancialmente nesse carater o principio diretivo da sua disciplina, o seguro de vida parece rebelar-se a este conceito. As paginas dedicadas por VIViante, à critica da aplicação do conceito de contrato de indenisação ao seguro de vida, estão sempre vivas na mente de qualquer estudioso do problema. E' corrente agora na doutrina assecurativa, no recentissimo tratado francês de Picard e Besson ou no de Hemard ou no de Sumien, como no recente tratado alemão de Bruck, como no classico de Ehrenberg, assim como no de Ehrenzwerg, como nas coletaneas economicas de GoBBI, a constante afirmação da impossibilidade de colocar o seguro de vida no ambito de um contrato de indenisação. (1)

No tratado de direito civil de Colin et Caprtant lê-se à pagina 739, volume II (edição de 1935), a afirmação breve de que é "falso" reduzir todos os ramos de seguro ao conceito indenitario e se admite efetivamente a definição de HEMARP fundada sobre um conceito diverso.

No verbete dos Seguros em geral, do Novo Digesto Italiano, redigido pelo dr. GASPERONI encontra-se a mesma afir-

(1) Cfr., para a bibliografia, alem dos tratados recentes recordados no texto, o n..$^{\circ} 1.862$, vol. IV, 5. ${ }^{\mathrm{a}}$ edição, do Trattato de VIVANTE. 
mação que é completada pelo franco reconhecimento da impossibilidade de formular um conceito unitario do seguro.

Esta coincidencia de afirmações dos maiores, talvez, civilistas francêses destes ultimos anos e do jovem estudioso italiano, parece consagrar uma opinião já tornada comum. $E$ ' esta opinião que explica porque, nas mais recentes leis sobre seguro, evita-se dar uma definição do contrato de seguro. (2)

Chegou-se assim a uma situação quasi paradoxal.

Na consciencia comum, nas leis de todos os países, na doutrina economica, todos os ramos do seguro são considerados como sub-especies de um unico contrato, e esta conviç̧ão era ainda generalisada na doutrina do seculo passado, na qual é corrente a afirmação de que o contrato de seguro é um contrato de indenisação e que mesmo o seguro de vida corresponde a esse conceito. $\mathrm{Na}$ doutrina mais recente, contudo, especialmente italiana, alemã, francêsa, é

(2) Como se sabe, o primeiro a ser regulado legislativamente foi o seguro marítimo, de há muito o mais importante, até quasi o fim do século XIX. O seguro terrestre foi disciplinado na Europa, primeiro, na lei belga de 1874 e no codigo comercial hungaro de 1875, tendo sido aquela a fonte da disciplina dos seguros nos numerosos códigos de comercio publicados nos paises latinos na segunda metade do século XIX. Na America do Norte, leis especiais sobre o seguro, tambem terrestre, se encontram desde a metade do século XIX (por exemplo, Massachussets, 1861; California 1872; etc.). Em geral, essa disciplina só considera de modo especial algumas formas de seguro: essencialmente, o seguro contra incendio, nos seguros sobre as coisas, e o de vida. Com o século $\mathrm{XX}$, em correspondencia ao maior desenvolvimento dos seguros e ao exercicio de novos ramos, a disciplina do seguro é ditada em lei especial; assim, a lei alemã de 30 de maio de 1908; a Suiça, de 2 de abril de 1908; a do Estado de Nova-York, de 7 de maio de 1909 (nos Estados Unidos, a disciplina do seguro é de competencia estadual e não federal). O movimento acentua-se depois da guerra de 1914-18; a lei austriaca de 23 de dezembro de 1917; dinarmaqueza, de 15 de abril de 1930; francesa, de 13 de julho de 1930; norueguesa, de 6 de junho de 1930; rumena, de 4 de julho de 1930; finlandesa, de 12 de maio de 1933; tchecoslovaca, de 3 de julho de 1934 ; — acentuando-se, ao mesmo tempo, a emanação da legislação de controle, primeiro em alguns e depois em muitos Estados. Nos códigos civís mais recentes, como o brasileiro, os seguros são disciplinados no código civil. 
agora corrente, ao contrario, a afirmação oposta; nega-se o carater indenitario do contrato de seguro de vida e consequentemente põe-se em duvida a unidade do contrato de seguro.

A doutrina brasileira parece-me ter ficado extranha à discussão (3), mas uma precisa e nitida visão do problema encontra-se no comentario de Clovis Bevilaqua aos arts. $1.432,1.440,1.471 \quad(4)$.

E' para mim motivo de satisfação chegar nestas paginas a conclusões analogas às da doutrina sul americana.

$2-\mathrm{O}$ conceito unitario do contrato de seguro foi encontrado no principio da "necessidade", por uma tendencia internacionalmente muito difundida que é talvez a mais frequentemente acolhida na doutrina germanica.

Esta tendencia (5) dá sentido à afirmação de que nas suas varias formas o seguro procura reparar uma necessidade eventual do beneficiario e que nesta sua função encontra a sua razão de ser. $O$ merito inegavel dessa tendencia consiste em haver aclarado a distinção entre seguro e jogo e identificado assim os caracteres do risco elaborando em correspondencia a noção do "interesse" asseguravel.

Com efeito, exatamente se observou (6) que, nas hipoteses do jogo e da aposta, o risco não é sinão uma conse-

(3) Cf., por exemplo, o comentario de Carvalho Santos, art.

(4) O código comercial argentino, por sua vez, em sua sistematização, é, talvez, o que mais acentua a unidade do contrato de seguro, subdividindo _- aliás de modo não recomendavel — a disciplina especial dos seguros terrestres em três secções (incendio, riscos agrícolas, vida), em lugar de adotar a dicotomia (danos e vida), como nos códigos italiano e brasileiro.

(5) Foi retomada na Italia, após varios anos de abandono, por Viterbo, Rivista di diritto commerciale, 1932, I, 40. Criticou ele, percucientemente, a teoria vivanteana, iniciando um movimento de reação contra esta e dando à teoria da necessidade uma formulação jurídica mais rigorosa de quanto precedentemente se fizera, em conexão com a teoria geral dos contratos aleatorios.

(6) Cf., VrTerbo, ob. cit., exactamente observando que nos contratos aleatorios bem como no seguro, embora o "contrato" não seja condicionado, é, ao contrario, "necessariamente condicionada" (a verificação do risco) a "prestação de uma das partes". 
quencia do fato de se haver jogado ou apostado - pois de outro modo o evento seria indiferente; na hipotese do seguro, ao contrario, o risco preexiste ao contrato.

$\mathrm{E}^{\prime}$ esta a inegavel diferença entre o contrato de seguro de um lado e o de jogo ou aposta do outro; o seguro corresponde a um risco subsistente objetivamente para o patrimonio do beneficiario, ao contrario do que acontece no jogo.

Coerentemente ensina-se que o seguro não pode subsistir faltando um "interesse" asseguravel (7); é necessario que o beneficiario do seguro se encontre em uma situação tal que o sinistro se converta para êle em um dano, e daí não ter interesse na verificação do sinistro.

Este principio constitue um principio fundamental na legislação e na pratica, como que o esteio da instituição. Se fosse possivel segurar-se por um evento, a respeito de cuja verificação não se tivesse um interesse contrario, o seguro não seria nem util e nem mesmo tecnicamente possivel, porque o beneficiario tornar-se-ia um provocador do sinistro, para lucrar a indenisação.

E' efetivamente o que sucede todas as vezes em que, por circunstancias anormais, o interesse do segurado em que não se verifique o sinistro exerce uma influencia psicologica inferior ao seu desejo de lucrar a indenização e não encontra um obstaculo suficiente nas normas, refertas por isso frequentemente de caracteres penais, (8) que atingem a fraude nos seguros.

(7) E' o aspecto mais investigado na doutrina alemã, desde - clássico tratado sobre os seguros de EHrenberg, Leipzig, 1893, até ao amplo tratado de Krscr, que dedica ao interesse seguravel todo o terceiro volume (Berlim, 1932).

$\mathrm{Na}$ doutrina italiana, o ensaio mais desenvolvido é o de FERRARINI, nos Saggi in scienze assicurative, vol. I, publicados pela Real Universidade de Pisa.

A doutrina do interesse é, talvez, hoje, o aspecto mais estudado da teoria do seguro especialmente nas doutrinas italiana e alemã. Vivamente discutida é a questão de saber si o interesse deve ser objetivo ou, ao contrario, se pode ser subjetivo.

(8) Note-se que essas normas se acham entre.as pouquíssimas que tutelam a execução de um direito obrigatorio, ao passo que, em geral o direito penal explica sua tutela em um campo correspondente ao dos direitos de personalidade e dos direitos reais. 
Na praxe, o mesmo principio costuma ser expresso na conhecida maxima de que o seguro não deve ser fonte de lucro para o segurado (beneficiario) (9).

E' desnecessario lembrar as numerosas consequencias deste principio, muito conhecidas por quem quer que tenha pratica da materia, assim como são conhecidas as numerosas clausulas contratuais (10) que procuram reforça-lo.

Menos frequentemente talvez se salienta que este principio se relaciona com um carater que todavia é proprio do contrato de seguro. Neste a lei considera o segurador e o segurado como aliados, ambos interessados em que não se verifique o sinistro ou em limitar suas consequencias, cooperação que, ao menos no gráu em que se verifica no seguro, não encontra simile nos outros contratos. (11) man

Mas se estes são os meritos da teoria da necessidade, convem ainda reconhecer que ela não consegue construir unitariamente o seguro e unificar o seguro de vida e o. se-

(9) Cf. WeEns, Du principe que l'assurance des choses est un contrat d'indemnité, París, 1927.

(10) Por exemplo, não segurando a coisa pelo inteiro valor, mas deixando um "descoberto", como se costuma dizer, em rélação ao qual, como se diz, o segurado é segurador de si mesmo.

(11) Isso se revela na disciplina peculiar em muitas legislações da conclusão do contrato de seguro em relação às reticencias e às falsas declarações do segurado, ainda que de boa fé (cfr. art.o 429 , cod. com. ital.). Essa disciplina, que é tradicional, não pode ser identificada com a disciplina geral do erro e é a respeito dessa disciplina que conserva significado particular a máxima tradicional, que de outra forma seria hoje em geral propria a qualquer contrato, de que o contrato de seguro é um contrato de boa fé, ou, como preferem escrever os escritores anglosaxonios, uberrimae fidei. Dessa "cooperação" do segurado se originam, não raro, as sanções de decadencia do direito é indenisação, que, na disciplina do contrato de seguro, são particularmente numerosas e que convem manter cuidadosamente distintas dos casos de nulidade do contrato; da mesma forma convem pois distinguir as "obrigações" do segurado (cuja ienexecução dá lugar ao resercimento dos danos) e os seus “onera" (cuja inexecução, algumas vezes embora sem culpa, dá lugar á decadencia do direito à indenização). Cfr. art. 108, D. n. 2063 de 7 de março de 1940. 
guro de danos, como especies diversas, mas todavia sempre de um unico contrato. (12)

E' obvio efetivamente que, mesmo no seguro de vida, se pode falar da "necessidade" com referencia à geral e fundada aspiração de cada um de deixar aos proprios herdeiros uma importancia ou de beneficiar um terceiro em tal eventualidade, mas é todavia obvio que com essa afirmação se disfarça o problema antes de resolvê-lo.

No seguro de danos, com efeito, a necessidade é do beneficiario e assim subsiste não somente como necessidade prevista no momento da conclusão do contrato, mas como dano atual do beneficiario no momento da verificação do sinistro; é ao dano provocado pelo sinistro que colima a indenisação; é o beneficiario que deve demonstrar o seu interesse asseguravel em falta do qual não pode subsistir um seguro valido.

Se geralmente se fala a este proposito de "segurado", isto se dá somente porque, no seguro de danos, a pessoa do segurado e a do beneficiario geralmente coincidem; mas muitas vezes essa coincidencia não ocorre (p. ex. no seguro por conta de quem compete), sendo então constante a doutrina e a jurisprudencia que exigem a subsistencia do interesse asseguravel no beneficiario e não no segurado (13). Este principio, se são exatas as nossas premissas, é perfeitamente natural, porque é o beneficiario e não o segurado aquele que, lucrando a indenisação, deve não ter interesse na verificação do sinistro.

No seguro de vida, vice-versa, podemos bem encarar no momento da conclụsão do contrato a previsão de uma futura necessidade da parte do estipulante, mas nunca, ao contrario, se exige a demonstração dum dano do beneficiario

(12) Os que sustentam a teoria da necessidade, p. ex. GobBi, apressam-se, com efeito, em declarar que o seguro de vida não constitue um contrato de indenização.

A mesma afirmação lê-se em Viterbo, op. cit. p. 51.

(13) E' justamente essa a justificação da conclusão do seguro por conta de quem compete, a respeito do qual cf. o vol. de A. DoNaTI, L'assicurazione per conto di chi spetta. Roma, 1934. 
no momento do sinistro e em seguida a êle. A possibilidade de ser beneficiario da indenisação não é subordinada, ao contrario do que acontece nos seguros de danos, à presença de um interesse seguravel. A indenização não encontra o seu limite na medida do dano do beneficiario, como, ao contrario acontece nos seguros de danos, mas coincide com a importancia livremente fixada, a priori, na conclusão do contrato. Isso se reflete na profunda diferença que parece assumir nesse campo a teoria do interesse, que por esta causa muitos - como no recente tratado de BRuck - sustentam inaplicavel ao seguro de vida.

As leis falam da necessidade de um interesse do estipulante a respeito da pessoa sobre quem se contratou o seguro (assim no código italiano, argentino e brasileiro) ou da necessidade de um consentimento escrito da pessoa a cujo respeito se contratou o seguro (como na lei francesa), mas com isso cuidam do interesse do estipulante e não do beneficiario e vão assim ter a um conceito que, não obstante a identidade do nome empregado, pode aparecer bem diverso daquele do interesse no seguro de danos.

A teoria da "necessidade" é porisso verdadeira e insuficiente ao mesmo tempo e assim somente é verdadeira parcialmente.

Verdadeira no indicar a função economica do seguro e estabelecer a distinção jurídica entre seguro e jogo; mas insuficiente quando não consegue, depois, mostrar a constante e rigorosa relevancia juridica desta função economica e renuncia em substancia a este alvo, quando reconhece que o seguro de vida não é um contrato de indenisação. (14)

Por outro lado, entanto, se do seguro privado passarmos ao seguro social, encontraremos mesmo na hipotese do ris-

(14) E' essa, em substancia, a crítica de Vivante, vol. IV, pág. 355, n. $^{\circ} 1.863$, à teoria da necessidade, segundo a formulação de Gobri e à teoria análoga do interesse legítimo de EHrEnBERG.

Essa crítica não é superada nem mesmo pela mais recente formulação da teoria da necessidade, de VITERbo, que aliás afirma explicitamente que, embora o conceito da necessidade seja comum ao seguro dos danos e ao de vida, no seguro de vida não ha "dano" (cf. p. 52, ob. cit.). 
co de morte principios que são os do seguro de danos; o direito à indenisação é limitado aos que vivem a cargo do segurado; é em função das importancias que a vitima ganhava no seu trabalho; varia de acordo com as varias relações do beneficiario com a vitima. Portanto, a indenisação é conceitualmente subordinada à existencia de um dano e a sua medída é em função da medida do dano, ao menos quanto aos principios.

Se, após a consideração do risco de morte, passarmos a considerar os seguros de acidentes (infortunios e molestias) encontrar-nos-emos indubitavelmente embaraçados em sua classificação, visto como parecem êles quasi assinalar o termo medio entre o seguro de danos às coisas e o seguro de vida, tornando assim a mostrar a existencia de um conceito unitario do seguro, não obstante sua divisão em varios ramos, sujeitos a regras diversas. E' significativo que no tratado de direito civil de Colin et Capitant à peremptoria negação do carater indenitario do seguro de vida a pagina 735 volume II, siga-se após, na página 757 , o reconhecimento de que o seguro de vida e o seguro de acidentes entram ambos na mesma categoria do seguro de pessoas, mas que o carater indenitario, assente no seguro de vida, é subsistente para sempre, embora passe para segundo plano, no seguro de acidentes.

E' aliás sintomatico que a doutrina mais recente embora negando a existencia de um carater indenitario no seguro de vida, refute as teorias que, no seculo passado, na Alemanha e na França, exemplificativamente com THöL e Huc, haviam procurado explicar o seguro de vida de acordo com uma ordem de ideas diversa da aceita para os seguros de danos, teorias que nem são lembradas na literatura mais recente sobre seguros.

3 - Foi exatamente o intento de chegar a uma teoria unitaria do seguro que levou VIVANTE - embora reconhecendo a distinção acima lembrada entre seguro, por um lado e jogo ou aposta por outro - a formular a sua teoria da empresa, a qual exerceu indubitavelmente uma influencia 
profunda na doutrina e uma influencia decisiva sobre o desenvolvimento legislativo mais recente.

A unidade do seguro se encontra, segundo Vivante, no elemento, que este mesmo autor diz técnico, da empresa; na circunstancia de que em todos os ramos de seguro este se exercita pelo segurador sistematicamente, com fundamento no calculo de probabilidade, tanto que, encarando a massa dos contratos, se substitue ao caracter aleatorio, proprio do contrato singelo isoladamente considerado, a possibilidade de uma previsão da entidade dos sinistros segundo os principios do calculo de probabilidade.

Esta teoria contem um inegavel fundamento de verdade. Não somente o contrato de seguro isolado constitue uma anormalidade, mas o seu carater não o tornaria apto a preencher a benefica função que é assumida pelo seguro (16); é somente atravez a massa dos contratos, que o segurador, eliminando o carater aleatorio de cada contrato considerado singularmente, pode fazer frente efetivamente ao risco; é assim pela massa dos contratos, que aquele risco, que singularmente se não poderia suportar, reparte-se em substancia entre todos os segurados, cada um dos quais substitue assim o pagamento de um premio certo e do qual pode suportar o onus, à eventualidade de um risco (17) que ao invés surgiria muito grave (18).

(15) A teoria vivanteana da empresa não visa distinguir o seguro do jogo, porque é evidente a observação de que tambem este pode ser exercido sob a forma de empresa e com a aplicação do cálculo de probabilidades, muitas vezes mais rigorosamente do que no seguro. O pensamento de Vivante é claro a esse respeito (cfr., por exemplo, n..$^{\circ} 1.862$, vol. IV, pág. 351, da 5. ${ }^{a}$ edição), si bem que muitos o tenham entendido mal.

(16) Por isso, para Vivante, aproximar-se-ia do jogo. Foi essa observação que fez nascer o equívoco precedentemente denunciado.

(17) Sabe-se que dessa circunstacia partiu HaymanN, nas suas profundas pesquisas (Leistung und Gegenleistung im Versicherungs vertrag, Berlim, 1933) sobre o problema da sinalagmaticidade do contrato. Qual, pergunta HAYMANN, a contra prestação do segurador? qual a causa do contrato nas hipóteses em que o risco não se 
E' assim sabia diretriz a das recentes legislações que nos varios paises, ora para alguns ramos, ora por todos, (como na Italia e no Brasil e, desde 1938, na França) su-

verifica? Para responder a esta pergunta alguns (por exemplo MossA, na Italia), identificam a contra-prestação do segurador, não na obrigação de pagar a indenização, mas na constituição do fundo de premios, graças ao qual a indenização poderá ser paga e que deve ser calculado em relação a qualquer contrato de qualquer modo concluido.

Em minha opinião, tal orientação é erronea, originando-se da confusão de duas ordens de normas diversas e diversamente sancionadas. Com efeito, nenhuma norma sanciona o direito do segurado "singel" "à constituição da reserva matematica" ou do fundo dos premios e é, por isso, impossivel reconhecer, na constituição desta, a contra-prestação do segurador, que é, ao contrario. inequivocamente estabelecida no pagamento da indenização.

A constituição da reserva matematica e do fundo dos premios é imposta, nas leis de controle das empresas de seguros, por via de direito público, e sancionada por via de direito público. Cfr. D. 1186 de 3 de abril de 1939 e D. 2063 de 7 de março de 1940 .

Isso não significa que "os segurados" não gozem de nenhum direito sobre a reserva matematica, porque esse direito é, ao contrario, frequentemente estabelecido nas leis de controle (por exemplo, na lei italiana de 29 de abril de 1923), mas trata-se de uma "garantia coletiva", que não diz respeito ao "singel" segurado, mas aos "segurados", e que só "coletivamente" se pode fazer valer.

E' sob esse aspecto que se patenteia a importancia das teorias da empresa e da formulação francesa da mutualidade, expostas e criticadas no texto. Cfr., tambem, Colin et Capitant, Traité de droit civil. vol. II, pág. 764 (edição de 1935).

$\mathrm{Na}$ realidade, o problema encarado por HAYMANN encontra a sua solução na observação de que o carater sinalagmatico do contrato não contrasta a tese de que a prestação de uma das partes seja condicional; é esse, como bem mostrou Viterbo, ob. cit., o carater comum do seguro e do jogo. E' obvia a distinção entre a condição que (acidentalmente) pode referir-se a todo o contrato e a condição que (necessariamente, nos contratos aleatorios) se refere à prestação de uma das partes (cf. Viterbo, ob. cit., p. 59 .

Deve-se observar, também, que a obrigação de pagar a indenisação pode também ser assumida pelo segurador gratuitamente. A entrega de apólices gratuitas por parte das companhias (isto é, sem o pagamento de premios, nem por parte do segurado, nem por parte de um terceiro) é naturalmente rara, mas não está excluida (v. Viterbo, ob. cit.): ela encontra limites na possibilidade de as sociedades comerciais (como as companhia de seguros) realizarem atos a título gratuito e nas normas, hoje ditadas nas legislações do controle, sobre a constituição da reserva matematica e do fundo dos premios, que devem ser naturalmente constituidos, tam- 
bordinam o exercicio do seguro à existencia de mutuas ou sociedades comerciais que, pela larguesa dos capitais obtidos, dêm a segurança de poder exercitá-lo naquela vasta

bem, em relação às apolices emitidas gratuitamente, porque do contrario sairiam prejudicados os outros segurados. Por isso, a emissão de apólices gratuitas só pode verificar-se, constituindo a reserva técnica correspondente à apólice e nos limites e com as formas nas quais as sociedades comerciais podem realizar atos a título gratuito (cf. os meus Appunti di diritto commerciale, vol. II, Societá, $3 .^{2}$ edição, pág. 69).

Quando, todavia, tais limites são observados, a apólice pode, validamente, ser entregue a título gratuito, e a disciplina à qual é submetida a obrigação do segurador continua sendo a do seguro; a disciplina do seguro é a aplicavel a toda a relação jurídica (por exemplo, tambem, em relação às falsas declarações ou reticencias do segurando), exceção feita, evidentemente, para o que concerne ao premio ou à prestação do premio não devida, dada a gratuidade do seguro.

Por isso, o ensinamento corrente, que faz do premio um elemento "essencial" do seguro, não é inteiramente exato, e não é, por isso, inteiramente exato qualificar o contrato de seguro como um contrato "necessariamente" a titulo oneroso, si bem que tais afirmações correspondam à realidade na quasi totalidade dos casos. Em rigor, a prestação do segurador é das que podem ser assumidas tanto contra o pagamento de um premio (hipóteses normais), como gratuitamente (hipóteses excepcionais), e a disciplina da relacão jurídica é (salvo no que concerne ao pagamento do premio) idêntica nos dois casos. O seguro é, portanto, tão compativel com a gratuidade, como com a onerosidade do contrato.

Esse é, de resto, o ensinamento comum para o contrato de renda vitalicia, cujas analogias com o seguro de vida são evidentes: cf. cód. it., arts. 1789-1790; brasileiro. 1424.

Cf., de um modo geral, sobre a compatibilidade dos varios contratos com a onerosidade e a gratuidade da atribuição, o volume bastante conhecido de HoEnIGER, Gemischte Verträge, 1913.

Outro problema é o do reflexo das normas das doações na disciplina da emissão de uma apólice gratuita. Ele nos reporta à discussão sobre o conceito de doação que SAvigny concebia como uma causa geral de atribuição patrimonial (à qual, portanto, podiam corresponder diversos negocios jurídicos) e que a tradição francesa concebe, ao contrario, como um contrato. A indagação mais profunda deste problema, como sobre o problema estreitamente conexo das doações indiretas, e sobre quais dentre as regras ditadas pelo contrato de doação são igualmente aplicaveis às doações indiretas, continua sendo a de Ascolı, no seu Trattato delle donazioni, Pisa, 1898.

(18) E' justamente por isso que a doutrina francesa fala, como veremos, da mutualidade de qualquer seguro, e Rocco por sua vez define o segurador como um intermediario no risco. 
escala, independentemente da qual não pode desempenhar sua função (19).

Mas, não: obstante isto, a teoria vivanteana não se torna por seu lado satisfatoria.

Prescindindo dos casos, raros mas não rarissimos, de contratos de seguro concluidos para riscos que têm um carater de unicidade e escapam à possibilidade de previsão com assento em calculo de probabilidade (20), é evidente que a teoria vivanteana (21) não alcança um carater "juridico" do contrato de seguro, mas indica um presuposto técnico da industria seguradora e da sua função economica.

Este presuposto não constitue um caracteristico tão somente de seguro, nem pode assumir a caracteristica necessaria do contrato.

Do primeiro ponto de vista é efetivamente facil observar que este presuposto se encontra tambem em uma outra serie de operações e de contratos: os bancarios. E' evidente efietivamente que a função economica do banco pressupõe por seu lado uma pluralidade de "depositos" (22); somente graças à pluralidade dos depositos é que o banco, mantendo-se sempre em condições de fazer frente aos pedidos de reembolso póde todavia utilisar parte dos deposi-

(19) Em geral. é exigida a subsistencia de uma sociedade "anônima ou de uma mutua e são determinados capitais mínimos em função dos ramos exercidos e da extensão do territorio onde a industria é desenvolvida. Cfr. D. 1186 de 3 de abril de 1939 e D. 2063 de 7 de marco de 1940.

(20) Por exemplo, as expedições cientificas polares. Especialmente na praxe anglo-saxonia, o seguro de um risco com carater único não é raro.

(21) Como as formutações análogas de Brunetti e de SalanDRA, nos seus estudos em Assicurazioni, 1935-1,409 e 1,28. Cf., para a critica, o meu estudo sobre a Approvazione amministrativa della polizza vita, em Assicurazioni, 1936-1,1, e o estudo de A. Donatr sobre a teoria da empresa, em Assicurazioni, 1937, alem do estudo já citado de Viterbo, destinado especialmente a demonstrar a insuficiencia dessa teoria a respeito da distinção do jogo.

(22) Emprego o termo em seu significado corrente, prescindindo da questão de saber si os depósitos bancarios são sempre depósitos, no rigoroso sentido desse termo jurídico. 
tos para aplicações (23), contando com a circunstancia de que, no fluxo dos depositos e das retiradas, um certo "fundo" subsiste constante e que este é assim tornado disponivel para os negocios. Daí poder o banco exercitar sua função de intermediario de credito. Enquanto a simples operação bancaria se reduz juridicamente às figuras do mutuo, do deposito e assim dizendo, é inegavel a importancia que assume, economica e juridicamente, esse exercicio sistematico que é proprio do banco, importancia que todavia não autorizaria a configuração de contratos autonomos.

Do segundo ponto de vista é evidente que um contrato de seguro concluido isoladamente não preencheria a função economica do seguro, mas permaneceria contudo sempre juridicamente um contrato de seguro e não se transformaria, ao contrario, como deveria derivar das premissas de VIvanTe, em um contrato diverso. Tanto é isso verdade que as leis que em linhas gerais vedam a conclusão de contratos de seguro a empresas que não correspondam aos caracteristicos legislativos fixados (por ex. anonimas com capital determinado) estabelecem a nulidade ou a anulabilidade do contrato de outro modo concluido (24); cominam eventualmente sanções, mas com isso mesmo reconhecem que,

(23) Que a prudencia pretende a curto prazo e de facil liquidação, aconselhando a distinção entre os bancos e os institutos de Minanciamento, a medio e ainda mais a longo prazo, ou os que empregam economias em ações das sociedades comerciais.

(24) A meu ver, pois que o objetivo dessas normas é a tutela do segurado. a sua violação importa, em geral, na resolubilidade do contrato tão somente em favor do segurado. Cf., para o direito italiano, os meus estudos sobre Società di capitalizzazione e Sull'approvazione amministrativa delle polizze, em Assicurazioni, $1934,1,184$ e $1936,1,1$.

Em lugar de contrato "invalido", poder-se-ia falar de contrato "irregular".

Aliás, é frequente, agora, que as normas que só permitem conclusão de um contrato em determinados casos, quer para tutelar a contraparte, quer para fins de carater geral, importem, em relação ao contrato depois concluido sem a sua observancia, em sanções (às vezes somente por meio de multa) que, muitas vezes, não são exatamente as da nulidade ou anulabilidade do contrato, segundo os esquemas conhecidos do direito civil. Pense-se, por exemplo, no recebimento de depósitos por parte de institutos não autorizados, em paises onde essa autorização é exigida. 
em si mesmo considerado, aquele contrato constitue para sempre um contrato de seguro (embora nulo ou anulavel ou resoluvel) e não um contrato diverso. Isso porque o exercicio sob forma de empresa constitue um presuposto para que o seguro possa realizar sua função, mas não entra como parte do que se costuma chamar a causa do contrato, analogamente ao que, recordamo-lo, se poderia observar nas operações bancarias.

A doutrina de Vivante é retomada em sua substancia na doutrina francêsa mais difundida. Assim Hemard, em seu Traité, (vol. I, p. 73), define o seguro como o contrato no qual o premio pago pelo segurado corresponde ao direito deste de obter, para si ou para outrem, uma prestação no caso de ocorrencia do sinistro "par une autre partie, l'assureur, qui, prenant en charge un ensemble de risques, les compense conformément aux lois de la statistique".

Esta definição é, aliás, a mais acatada geralmente na doutrina francêsa (25). Encontra ela (26) todavia as mesmas objeções apresentadas à teoria vivanteana. Por um lado, erige em momento essencial um elemento técnico que, de tanto, refere-se, não à caracterização do contrato no quadro de outros contratos, mas à validade ou regularidade do contrato mesmo; de outro lado, esse elemento técnico pode encontrar-se, mutatis mutandis, tambem em outras operações e nã̃o póde por isso mesmo ser elevado a elemento caracteristico fundamental do contrato de seguro.

Resumindo, poder-se-ia dizer que a tése de Vivinte, como a da doutrina francêsa, indica a base técnica da industria seguradora (27), mas não a caracteristica juridica do contrato.

(25) Onde, por isso, ensina-se que base constante do seguro é a mutualidade e, portanto, a concorrencia de mais segurados, a qual permite ao segurador, constituido em companhia ou como mutua, compensar os varios riscos.

(26) No mesmo sentido da doutrina francêsa cfr. na Argentina, o comentario de Segovia ao art. ${ }^{\circ} 549$ do cód. com. arg..

(27) Justamente por isso, tendem elas a ser traduzidas, legislativamente, não na disciplina do contrato de seguro, mas na disciplina de controle das empresas seguradoras. 
Isso não significa, que o elemento assim posto em evidencia não seja relevante, mesmo juridicamente.

0 exercicio sistematico de uma atividade é por si mesmo, efetivamente, causa de consequencias juridicas (28); a conclusão sistematica de uma serie de contratos de seguros (ou, analogamente, bancarios) dá lugar a uma serie de consequencias juridicas, que seria erroneo esquecer.

Vivante indicou varias (29), no campo do direito privado. As mais importantes se encontram forçosamente no campo da legislação de controle especialmente sob este duplo aspeto: a) da irregularidade, que já mencionámos, dos contratos de seguro concluidos de outra maneira; b) da instituição, tambem já recordada, de uma garantia coletiva, a favor dos segurados.

Mesmo estas consequencias, confirmando a importancia que, até no terreno juridico, reveste o elemento posto em destaque por Vrvatiste, evidenciam que não se trata de um elemento que vize caracterizar o "contrato" de seguro no sistema dos contratos, mas de efeitos que, no ambito do seguro como em outros (30), derivam do exercicio sistematico de uma atividade sob forma de empresa, ou melhor, de grande empresa. Estas consequencias não atingem a disciplina privatistica do contrato, mas o direito publico da economia que se vai mais do que nunca agora constituindo.

E' aí, e não no campo tradicional do direito privado, que o exercicio sob forma de grande empresa adquire peculiar merciante.

(28) O exemplo classico é constituido pela doutrina do co-

(29) Cf., no tratado de Vivante, o n. ${ }^{\circ} 1859$, vol, IV, 5." edição. Cf., tambem, no comentario de Vivante ao título dos seguros no comentario do código de comercio editado; pela U. T. E. T. 6. ${ }^{\mathrm{a}}$ ediç., a mais recente exposição do pensamento do Mestre a esse respeito.

(30) Menciono novamente o bancario. Cf., particularmente, Greco, Corso di diritto bancario, 2. ${ }^{a}$ edição, Padua, 1936. Propõe-se para os bancos um problema de tutela dos depositantes, o qual não é muito diverso do da tutela dos segurados nos seguros de vida. Ainda mais evidente se apresenta esse problema na "capitalização", e, de fato, as empresas de capitalização tendem, hoje, a ficar sujeitas às mesmas normas das de seguro de vida. 
importancia juridica e é, a meu ver, fruto de um equivoco esquecer esta distinção.

4 - Realmente para encontrair a unidade do contrato de seguro em suas varias formas é necessario penetrar na historia das doutrinas, e mantendo aqueles elementos de verdade proprios das doutrinas ora recordadas, voltar ao conceito do contrato de seguro como contrato de indenização, o que é hoje unanimemente acolhido para os seguros de danos, mas recusado na doutrina européia para o seguro de vida.

O conceito unitario do contrato de seguro não póde encontrar-se senão identificando o "dano" que o seguro, mesmo de vida, viza reparar.

5 - E' generalizado o conceito de que a vida humana constitue um bem inestimavel e desta premissa, sustenta-se, decorre a justificação da norma que permite no seguro de vida o seguro por um valor qualquer, não limitando portanto a indenização em função da prova de um dano.

Por isso, sustenta-se que o seguro de vida tem sempre por objeto o ressarcimento de um dano, mas este, pela inestimabilidade da vida humana, pode ser avaliado a priori em uma soma determinada, independentemente da demonstração concreta do mesmo, contrariamente ao que acontece nos seguros de danos.

A observação é seguramente exata, mas ouso lembrar que ela não é suficiente para explicar de um lado as varias peculiaridades do seguro de vida e de outro manter aquele caracter indenitario que somente pode justificar a unidade do contrato de seguro em seus varios ramos.

Primeiramente póde-se salientar que a inestimabilidade da vida e da pessoa humana in genere atem-se ao seu valor extra-patrimonial e afirma-se com ef eito juridicamente em relação ao reconhecimento geral da liberdade juridica. Não poderia ela efetivamente ser invocada juridicamente em re- 
lação aos escravos (31). No terreno patrimonial, a vida humana pode ser objeto de avaliação, como demonstra a praxe dos seguros sociais e como de resto tem lugar nas varias hipóteses nas quais o juiz deve fixar um ressarcimento por homicidio ou lesão pessoal.

As normas do seguro de vida apresentam-se, ao contrario, identicas, mesmo nas hipóteses nas quais a justificação do seguro se encontra exclusivamente em um interesse patrimonial. Assim nas hipóteses nas quais o credor assegura-se sobre a vida do devedor (32).

Mesmo em um campo geral, parece mais confórme à realidade da nossa época, a'dmitir-se que o seguro de vida tenha presente o lado patrimonial, do łque não seja admitir que vize em se procurar na indenização a compensação duma perda de caracter extra patrimonial.

Nos seguros de acidentes, encontra-se, por sua vez, como no seguro de vida, a possibibilidade de estabelecer a indenização em qualquer cifra e mesmo aqui parece dificil jus-

(31) Justamente com essa última observação inicia o seu estudo do seguro de vida (cap. XXV, Principios de direito mercantil, tomo I, pág. 58, 1. a edição. Lisboa, 1801) José DA Srlva Lissoa.

Note-se que o seguro de vida se apresentou, primeiramente, como um seguro sobre a vida dos escravos. Nessa hipótese, falar-se-ia hoje, de seguro contra danos. E', porem, oportuno acentuar que já naquela forma primitiva, o seguro de vida se apresentava com seus caracteres atuais, isto é, com a determinação da indenização em soma fixa, independentemente da demonstração do dano concreto, si bem que os escravos tivessem um preço de mercado.

Cf., Bensa, II Contratto di assicurazione, pág. 129; Prattoli, Rivista di diritto commerciale, 1936, I, 866, para as varias regras das primitivas formas de seguro de vida. Da primeira companhia brasileira de seguro sobre a vida dos escravos, dá noticia o Diario de Pernambuco de 11 de novembro de 1856, citado por Grlberto FreyRE, Nordeste, Rio, 1937, pág. 245.

Os economistas examinaram demoradamente o problema do homem livre como instrumento de produção e a possibilidade, portanto, de incluir o "homem" naqueles bens que constituem riqueza Para a conclusão afirmativa, sustentada por Pareto, Walras, Mc Cullock, PETty cfr. FISHER, The nature of capital and income, New York, 1906, cap. I, $\$ 2$ e $\$ 5$.

(32) Essa prática é, hoje, bastante difundida, quer no seguro por parte dos empregadores sobre a vida de técnicos empregados, dificilmente substituiveis, quer, combinada com os empréstimos fundiarios, no seguro do instituto de crédito hipotecario sobre a vida do devedor adquirente da casa a prestações. 
tificar esta possibilidade, encarando a inestimabilidade dos bens pessoais no terreno moral e visando, portanto, na indenização, quase um pretium doloris.

Em segundo lugar, costuma-se salientar que aquilo que parece obstar o reconhecimento de um caracter indenitario no seguro de vida é a circunstancia de que o dano ou a dôr são suportadas pelos que viviam a cargo do defunto e pelos parentes e amigos. Muito embora se possam amplamente determinar os limites destas categorias, a circunstancia acima mencionada não poderia permitir a designação descricionaria do beneficiario, como ao contrario acontece em todas as legislações. Este obstaculo não é transposto, saiientando a inestimabilidade dos bens pessoais.

Em terceiro lugar, pode-se observar que, no amplo quadro dos seguros de vida, penetram não somente os seguros por morte, mas, outrossim, os seguros em caso de vida e, assim, as varias formas de seguro de sobrevivencia (p. ex. seguro de casamento; seguro por uma soma ao atingir a maioridade; seguro de velhice, etc.). Nestas hipóteses, vigoram as regras do seguro de vida - e assim a possibilidade de estabelecer a indenização em uma cifra fixa, independente da concreta demonstração do dano - nem, nestas hipóteses, esta possibilidade poderia encontrar a sua justificativa na inestimabilidade dos bens pessoais.

6 - A solução do problema presupõe um apelo à doutrina do ressarcimento do dano.

1 De um ponto de vista naturalistico, as consequencias de lum evento danoso são multiplas e isso sob um duplo aspeto: o dos sujeitos que possam ser prejudicados por um mesmo evento; o das consequencias que o mesmo evento pode ter para cada pessoa.

O direito, ao disciplinar o ressarcimento dos danos, contratuais ou extra-contratuais, limita o ressarcimento somente a algumas das consequencias do evento danoso e isso sob ambos os aspetos, precedentemente considerados.

Em referencia às pessoas prejudicadas, nem todas são admitidas a fazer valer um direito ao ressarcimento. 
Quais as pessoas que são admitidas a reclamar o ressarcimento, não está ainda seguramente esclarecido na doutrina. Existe nos direitos, à feição francêsa, uma difusa tendencia a não limitar o ressarcimento somente àqueles cujo direito subjetivo foi violado, mas a admitir que mesmo as violações do direito objetivo dão lugar ao ressarcimento dos danos a favor daqueles cujos interesses (ainda que não constituam direitos subjetivos) são lesados (33). Não está porém previsto geralmente quais são estes interessados (34) (35).

Com referência às consequências para cada pessoa do evento danoso, é frequente na tradição francesa o principio

(33) E' por isso que, em materia de ressarcimento de danos por homicidio, opinam muitos que o direito ao ressarcimento não cabe aos herdeiros jure hereditario, mas - jure proprio - aos que viviam a cargo do assassinado. A mais profunda indagação sobre o problema se encontra em Carnelutti, Infortuni. Roma, Athenaeum, 1908.

(34) A fórmula do artigo 1382, francês; 1151, italiano; como tambem, agora, os arts 151 e 152 do ante-projéto brasileiro das obrigações, parecem concernir a todo ato culposo que tenha causado dano, violando a lei ou os bons costumes, mesmo sem violar um direito subjetivo alheio.

No direito alemão, no parágrafo 823 , são distintamente consideradas as violações do direito subjetivo e as de mero direito objetivo.

No direito suiço, no art. ${ }^{\circ} 41$ do código das obrigações, considera-se, de um lado, a violação da lei (ainda que não importe em violação de direito subjetivo), e, de outro lado, a dos bons costumes (que só importa em ressarcimento quando dolosa).

A melhor exposição resumida desses problemas se encontra na obra fundamental de Von TuHr, Der allgemeine Theil des Buerg. Rechts, 1913-1918, 3 vols. (na Enciclopedia Binding, edição Duncker \& Humblot) a qual resume toda a doutrina alemã até à guerra de 1914-18 e pode, por isso, constituir um ponto de partida nas questões dogmáticas, particularmente cuidadas na doutrina alemã. A obra do mesmo autor, traduzida em francês, Partie générale du code fédéral des obligations (2. ${ }^{\mathrm{a}}$ edição, Lausanne, 1933), resume e, em parte, completa a obra maior, precedente, particularmente com respeito ao código suiço Cf., alí, página 324 e seguintes, do vol I, no que concerne ao ressarcimento dos danos.

(35) Carnelutti, Danno e reato, opina que o direito ao ressarcimento pode caber somente aos interessadios "diretos e imediatos", utilizando, assim, o criterio ditado nos códigos para a delimitação dos danos ressarciveis na responsabilidade contratual e que, na tradição francesa e italiana, é tambem aplicado nos danos extra-contratuais. 
que são ressarciveis somente os danos diretos, imediatos e, se culposos, previsiveis (36).

Para os fins 'que temos em vista, basta observar que tais limites se referem ao dano ressarcivel segundo as disposições ide lei, sem excluir para as partes a possibilidade de estabelecer que o ressarcimento deve ter lugar dentro de limites mais amplos de que os legislativamente previstos.

7 - E' conhecida a distinção tradicional entre dano emergente ie lucro cessante.

Menos frequentemente destacada, mas não menos conhecida, é a distinção entre lucro cessante e beneficio esperado, ou, si se preferir, a distinção, no âmbito do lucro cessante lato sensu, entre o lucro cessante stricto sensu e o beneficio esperado. De um modo geral, inclue-se no ressarcimento tanto o dano emergente como o lucro cessante; nem sempre se inclue o beneficio esperado, porque, geralmente, é mais dificil para o credor demonstrar que a falta de sua nealização constitua uma consequencia imediata e direta do fato danoso.

Mas, ainda nesse caso, devemos perguntar: quando as partes tenham pactuado que o ressarcimento deve compreender tambem o beneficio com o qual o credor podia razoavelmente contar, já não estaremos, talvez, no âmbito do ressarcimento dos danos? Ao meu ver tambem neste caso há um ressarcimento dos danos. Na realidade, a diferença entre lucro cessante e beneficio esperado é mais uma diferença de grau que de natureza: lucro cessante é o ganho que se tinha o direito de auferir e que, por isso, se teria auferido, a não ser em circunstancias excepcionais;

(36) Código italiano, 1228, 1229; francês, 1150, 1151. 0 limite da ressarcibilidade aos danos diretos e imediatos costuma ser, por muitos, estendido tambem aos danos extra-contratuais; não assim o da previsibilidade. No código brasileiro, a liquidação dos danos extracontratuais é disciplinada analiticamente, para as varias hipóteses, nos arts. 1537 e seguintes; a dos danos contratuais compreende o que o devedor efetivamente perdeu e o que razoavelmente não ganhou (art.o 1059), como consequencia direta e imediata (art ${ }^{\circ} 1060$ ) do ato ilicito, e só limitadamente aos lucros previsiveis, quando a inexecução da obrigação consiste na falta de pagamento no momento e na forma devida (art. 1059, parág. 1). 
beneficio esperado é o que não se tinha o direito de aufe'rir, mas razoavelmente se teria podido obter.

A diferença entre o ressarcimento legal e o ressarcimento total é mais acentuada com referencia ao lucro cessante ou ao beneficio esperado dos instrumentos de produção, os quais podem desenvolver sua atividade por um longo periodo de tempo (37).

A. danifica as máquinas de B., o qual, por isso, não póde realizar um lucrativo contrato já concluido pela venda dos seus produtos, nem concorrer a outros negocios, deixando pois por muito tempo fechada a sua fábrica, com perda da clientela etc.

No encadeamento das varias consequencias do fato danoso, o direito intervem para limitar a ressarcibilidade às simples consequencias imediatas e diretas, de maneira que o ressarcimento de $B$. será, na realidade, somente parcial quanto maiores eram os beneficios mediatos e indiretos que ele esperava tirar de suas máquinas.

Mas, estariamos fora do âmbito do ressarcimento dos danos, si tais beneficios fossem ressarcidos, ou si as partes pactuassem o seu ressarcimento?

8 - Na conexão das varias consequencias danosas não é dificil perceber um grau diverso de segurança, relativamente à possibilidade de afirmar a relação de causalidade.

Esse diferente grau de segurança se exprime no fato de que, muitas vezes, o nexo causal só pode ser afirmado como probabilidade.

$E^{\prime}$ o que se verifica mesmo no dominio do dano emergente. Tanto em relação à influencia das concausas, como, quando-requerida, à previsibilidade do dano, devemse adotar, em substancia, criterios de "normalidade" e, portanto, de probabilidade.

(37) O célebre exemplo de Pothrer, Obligations, n..$^{\circ}$ 166-167, donde deriva a determinação dos limites dos danos ressarciveis nos direitos de tipo francês, referia-se justamente a danos em animais e, portanto, em instrumentos de produção. 
E' o que se verifica, em maior medida, com o lucro cessante, cujas normas probatorias sempre foram, de fato, discutidas na doutrina (38).

E' o que se verifica, sempre, com os danos "futuros", os quais tambem são ressarciveis (39), mas a cujo respeito nunca se poderá falar, a rigor, de "segurança" de sua verificação (como em relação aos passados), mas somente de suma "probabilidade", pelo fato mesmo de serem futuros.

E' o que, em medida tambem maior, se verifica, em relação ao beneficio esperado.

Daí a tendencia natural para determinar a priori a cifra do ressarcimento, tendencia tanto mais acentuada quanto mais arduo é o problema probatorio (40).

Essa tendencia é, pois, ainda mais natural quando o ressarcimento deve concernir não só ao dano emergente, mas tambem ao lucro cessante, ou mesmo ao beneficio esperado. A uma avaliação concreta do dano sucede, assim, uma avaliação abstrata, para usarmos da terminologia da doutrina alemã.

A avaliação abstrata do dano apresenta-se, por sua vez, em posição bem diversa em relação ao conceito do ressarcimento do dano, conforme a hipótese de fato concirna ao ressarcimento do dano emergente, ao do lucro cessante ou ao do beneficio esperado.

Com efeito, no primeiro caso, pelo menos normalmente, é possivel um cálculo objetivo do dano, e, portanto, a avaliação abstrata será inferior ou superior à realidade, podendo a ordem jurídica ser portanto levada a aumentá1a ou reduzí-la. A avaliação abstrata do dano, em tal hi-

(38) Cf., recentemente, Graziani, Appunti sul lucro cessante, in Annali $R$. Università di Perugia, 1925, e, na doutrina mais antiga, F. Mommsen, Beitraege zur Obligationslehre, 1875.

$O$ código brasileiro, art. ${ }^{\circ} 1059$, estabelece, com acerto, em materia contratual, a responsabilidade por aquilo que efetivamente perdeu o credor e por aquilo que razoavelmente não lucrou.

(39) Cf. Colrn et Capitant, Traitè II, pág. 174.

(40) Essa tendencia é, aliás, conhecida no direito tradicional, rom $o$ instituto da cláusula penal. 
pótese, pode, pois, revelar-se em contraste com o proprio conceito do ressarcimento do dano.

Ao contrario, no segundo ,caso, será normalmente impossivel chegar a uma avaliação concreta do dano que possua os requisitos de segurança, ou ao menos de suma probabilidade, que permitem afirmar que a avaliação abstrata se acha em contraste com o conceito mesmo do ressarcimento do dano. Por conseguinte, a reação da ordem jurídica só caberá em hipóteses excepcionais e diante de uma desproporção particularmente notavel.

Neste segundo caso, portanto, não só a avaliação abstrata será praticamente- preferida à avaliação concreta, como não se achará, si não excepcianalmente, em contraste com o conceito mesmo do ressarcimento do dano, ao contrario do que acontece no caso precedente.

Tal preferencia é tanto mais acentuada quanto mais o dano atinge instrumentos de produção susceptiveis de proporcionar, nos varios momentos, ganhos muitos diversos.

E' possivel, naturalmente, nessa ultima hipótese avaliar - ressarcimento com referencia ao ganho no momento do sinistro e, portanto, ficará o ressarcimento limitado ao lucro que, suposta a continuação da mesma capacidade de ganho, veio a faltar em consequencia do sinistro. E' obvio, porem, que não contraria em absoluto o conceito do ressarcimento do dano a consideração do maior lucro que, no correr do tempo, teria sido/realizado através do aumento da capacidade de ganho da fonte produtora danificada pelo sinistro.

1 Essas considerações podem, a rigor, ser aplicadas a qualquer instrumento de produção (máquinas, animais, homens), mas 'é evidente a sua peculiar relevancia quando aplicadas às pessoas humanas cuja capacidade de ganho costuma mudar, no correr do tempo, em medida particularmente notavel.

Limitando o ressarcimento, nesse caso, ao lucro do qual o sinistrado ou os seus dependentes ficam privados 
,em relação aos ganhos do sinistrado no momento do sinistro, tem-se em vista, na realidade, uma avaliação que, embora recomendavel por sua simplicidade (41), não pode em absoluto dizer-se seguramente correspondente ao dano acarretado.

Não está, portanto, em absoluto, em contraste com o conceito do ressarcimento do dano o admitir-se uma avaliação diversa, a qual leve justamente em conta a eventualidade de futuras mudanças nos ganhos do sinistrado, e é evidente que admitindo-se a possibilidade dessa avaliação diversa admite-se a possibilidade de avaliar o dano em ụma soma abstrata.

Isso acontecerá ainda mais, não se querendo prescindir das qualidades pessoais que, embora sem um valor patrimonial facilmente avaliavel, não poderiam ter negado o seu valor e o proprio valor patrimonial, como a beleza do corpo ou a saude.

E' obvio que, nessas hipóteses, só através de uma avaliação abstrata se pode ressarcir, ou melhor, reparar, o dano (42), tendo tal reparação não somente a função de um pretium doloris, mas tambem a de reparar os beneficios que, no terreno patrimonial, esses bens teriam permitido realizar.

E' natural, pois, que o ressarcimento do dano pessoal dê lugar, emquanto as partes podem disciplinar a priori o ressarcimento, a uma avaliação abstrata, a qual não contraria, em absoluto, o conceito do ressarcimento do dano, mas é, antes, uma consequencia do mesmo.

9 - As considerações precedentes nos autorizam a afirmar que, na medida em que o seguro possa ter por objeto um beneficio esperado em geral, será possivel re-

(41) Por isso, ela tem lugar, necessariamente, em materia de responsabilidade civil (cód. bras., art. ${ }^{\circ} 1.339$ ) e de seguros sociais.

(42) Correlatamente pode-se lembrar que uma das funções da clausula penal é a de avaliar a priori danos dificilmente avaliaveis concretamente, alcançando consequentemente, como observou IHERING, a proteção patrimonial mesmo de interesses não patrimoniais. 
conhecer uma avaliação abstrata do dano, e que, por sua vez, uma avaliação abstrata do dano pode ser só excepcionalmente compativel com o ressarcimento do dano emergente, mas normalmente compativel com o ressarcimento do lucro cessante e ainda mais com o do beneficio esperado (43).

10 - As considerações precedentes talvez bastem para oferecer ao leitor os elementos de demonstração da afirmativa que avançamos acerca da unidade do contrato de seguro como contrato de indenização em relação, nos seus varios ramos, respectivamente com a indenização do dano emergente ou do lucro cessante (ou beneficio esperado).

Essa indenização concerne, como se disse, ou somente ao dano emergente ou somente ao lucro cessante (e benefício esperado) e só excepcionalmente a ambos, de modo que a avaliação do dano tem lugar, por força, nos varios ramos de seguro, ou concreta ou abstratamente, mas não pode ter lugar, no mesmo ramo, segundo esses dois criterios ao mesmo tempo.

A) A tese por nós proposta não encontra, naturalmente, dificuldade no que respeita aos seguros contra danos ás cousas; constitue antes, nesse caso, o ensinamento comum. Tal ensinamento põe tambem em evidencia que a indenização assegurada não cobre, em principio, nessa hipótese, nem o lucro cessante, nem o beneficio esperado. Sabe-se que, tambem em materia de dano emergente, surgem dificuldades ulteriores para a delimitação do "valor" da coisa, o qual se deve ter presente para os fins do res-

(43) A relação entre seguro do lucro cessante e do beneficio esperado por úm lado e seguro contra acidentes por outro já foi sustentada por VALERI, Rivista di Diritto commerciale, 1909 II, 535 e por mim frizada em Assicurazioni, 1937, fasc. 4-5. Uma referencia ao beneficio esperado como objeto do seguro de vida em Donat Assicurazioni, 1937. Da vida como "energia produtora", objéto do reguro de vida, fala, por sua vez, Clovis Beviladua.

Do lucro esperado nos seguros falam, em linha geral, o código holandês, art. ${ }^{\circ} 242$, e o argentino, art.o 492, mas parecem referir-se à hipótese do seguro do lucro esperado antes no seguro sobre as coisas do que no seguro sobre as pessoas. 
sarcimento. Valor objetivo ou valor subjetivo? e - optando, como geralmente acontece, pelo valor objetivo valor de mercado, ou valor de uso? Essas perguntas traduzem, em substancia, em materia de seguros contra danos, a tendencia natural para adotar criterios objetivos de calculo do dano. Essa tendencia encontra sua natural explicação na sinalagmaticidade do contrato de seguro. À obrigação do segurador de pagar a indenização corresponde a do segurado de pagar o premio, e este só pode ser calculado na medida em que existam criterios objetivos para a apuração do dano e, por isso, para a determinação da indenização.

Essas observações explicam porque, em materia de seguros contra danos às coisas, há uma relutancia prática e legislativa em admitir a segurabilidade do beneficio esperado. Ele não é normalmente avaliavel com segurança por via objetiva, e, por isso, o seu ressarcimento é admitido quer o limite resulte diretamente da lei, quer resulte da praxe contratual - somente para aqueles beneficios esperados que são de facil e objetiva avaliação (44).

Isso explica, tambem, a excepcionalidade com que, em materia de seguro sobre as coisas, se adota a avaliação abstrata do dano. 0 exemplo tradicional dessa avaliação é o da claúsula "valha ou não" no direito marítimo, que, por sua vez, acha explicação na peculiar dificuldade que pode encontrar o ajuste do dano nos sinistros marítimos (45).

(44) Por exemplo, o maior valor da coisa no lugar de destino; a renda bruta de um predio, mesmo independentemente do seguro do pagamento do aluguel por parte do inquilino que a isso se obrigou (seguro, este ultimo, da solvabilidade do inquilino).

(45) A validade dessa cláusula é discutida no direito francês e no italiano, onde ela tende a ser admitida na jurisprudencia, ao passo que a doutrina muitas vezes ensina que ela não impede que o segurador calcule o real valor da coisa considerada no momento do sinistro, de maneira que a clausula não faria, em substancia, sinão tornar relevante o momento do sinisiro, em lugar do da conclusão do contrato, na avaliação da coisa.

Nos artigos 693 e 701 do código comercial brasileiro, nega-se valor particular a essa clausula, mas, por outro lado, admite-se em geral em certos limites a eficacia da determinação convencional do 
B) O seguro para o pagamento de uma soma na eventualidade de nupcias, nascimento de um filho e fatos semelhantes, constitue, ao meu ver, um seguro do dano emergente e não justifica integralmente sua disciplina, a tendencia corrente para confundi-lo com o seguro de vida, esquecendo $o$ aspeto precedente.

Nascimento e matrimonio constituem, economicamente, um "aumento de despesa"; são acontecimentos que importam em maior necessidade de dinheiro e, por isso, numa despesa que o seguro relativo visa a reparar. A ordem jurídica não é, de respeito, insensivel a esse ponto de vista, quer na sua organização tradicional, considerando muitas legislações como uma obrigação natural a dos genitores dotarem os filhos, quer nas normas, agora numerosas, de que ao matrimonio ou ao fato de ter filhos se confiram premios, isenções fiscais, etc..

Esse aumento de despesa não pode, porem, ser concretamente avaliado e deve, por isso, ser avaliado abstratamente em uma soma fixa, determinada a priori e devida independentemente da indagação do montante preciso desse aumento de despesa nos varios casos concretos. Tal circunstancia torna esse ramo próximo do do seguro de vida e, mais geralmente, do do seguro de pessoas.

A possibilidade de considerar esses ramos como análogos ao seguro de vida resulta, pois, da circunstancia de que o pressuposto da verificação do evento ao qual está subordinado o direito de indenização é obviamente constituido pela vida do beneficiario, e, por isso, tal elemento deve ser tomado em consideração no cálculo de probabilidade que preside à determinação do premio, paralelamente ao que sucede nos seguros de sobrevivencia.

Mas, seria erroneo esquecer, por isso, a consideração precedente. Na verdade, é facil acentuar que, mal a soma segurada vai além dos limites impostos por essa conside-

valor da coisa, podendo o segurador tão somente provar que a coisa valia, no momento da conclusão do contrato, no minimo um quarto menos. 
ração, a companhia seguradora caminha para a falencia. porque não poderá impedir o matrimonio ou a procriação por parte do segurado, interessado em provocar o risco considerado.

Isso demonstra que, tambem nesses ramos de seguro, seria ingenuo prescindir da subsistencia do interesse do segurado em que não se verifique (46) o evento segurado, porque de outra forma desaparece a propria possibilidade técnica do seguro.

Essa consideração explica porque a praxe seguradora, em geral, só conclue esses contratos para indenizações modestas (ao menos em relação à condição econômica do beneficiario), justamente para impedir que o beneficiario não contraia nupcias sinão para lucrar a indenização e que esta possa constituir um verdadeiro "lucro" para o beneficiario, isto é, uma vantagem bem maior que o aumento 'de despesa consequente às nupcias.

$E^{\prime}$ verdade, porem, que a lei prescinde da demonstração desse interesse, ao decidir a validade do contrato. Substancialmente, a subsistencia do interesse é legislativamente presumida, ao contrario do que sucede nos seguros sobre as coisas, e, analogamente, do que sucede, como veremos, em todas as hipóteses de seguros para o caso de sobrevivencia. $E$, pois, a praxe contratual que deve, na cautela da redação dos contratos, evitar esse perigo.

E subsequentemente a praxe contratual que deve frizar nesses casos, através da configuração concreta do contrato, a sua distinção do jogo, uma vez que o legislador não exige a demonstração da subsistencia do interesse seguravel, mas se limita a presumi-lo.

Fundadamente, parece-me que se pode falar de presunção desse interesse (47) por parte do legislador, porque

(46) Naturalmente, sob o aspeto da relação com a companhia e despesa provocada pelo evento!

(47) No sentido indicado na nota precedente.

de seguros e, portanto, da comparação entre indenização assegurada 
sem dúvida tal interesse subsiste na generalidade dos casos. E' somente partindo dess'a presunção que se compreende, em contraposição ao jogo, a formação desses ramos de seguro e a razão do seu reconhecimento jurídico.

C) O seguro da responsabilidade civil visa, por seu turno, ressarcir o segurado do que, para o patrimonio deste, é um dano emergente (isto é, a obrigação de ressarcir, por sua vez, o dano provocado).

Podie-se observar que a soma que para o patrimonio do segurado (por sua vez responsavel para com o terceiro) é um dano emergente, pode corresponder, ao contrario, no todo ou em parte, a um lucro cessante, si considerada na relação entre segurado responsavel e terceiro prejudicado.

Essa observação permite afinmar que pode ser diverso o dano que deve ser ressarcido por um primeiro responsavel pelo seu ressarcimento e por aquele que é, por sua vez, responsavel para com o primeiro.

Por isso, não há nada de estranho em admitir que uma indenização seguradora, que numa primeira relação constitue ressarcimento de um lucro cessante, constitua, ao contrario, numa segunda relação, ressarcimento de um dano emergente.

Fica, pois, superada a objeção que nega ao resseguro o carater de seguro da responsabilidade do segurador, com base na observação de que a indenização devida pelo segurado pode ser uma indenização de seguro de vida e não pode, por isso, corresponder, por parte do ressegurador, a um seguro contra danos. Essa consideração se revela inutil em face das observações precedentes, de modo que se confirma o conceito do resseguro como seguro da responsabilidade contratual do segurador para com o segurado (48).

(48) Seguro de responsabilidade civil e resseguro dão ambos lugar a três ordens peculiares de problemas, que me limito, aquí, a recordar, citando, para sua ilustração, as minhas notas em Assicurazioni, 1934/37, assim como os estudos de Demogue e Greco (sobre a ter- 
11 - Um segundo grupo de ramos de seguro concerne ao seguro, e por isso ao ressarcimento, do lucro cessante e do beneficio esperado.

Ao contrario do que normalmente acontece no ressarcimento do dano emergente, a determinação da indenização verifica-se a priori, através da fixação de uma soma que constitue a indenização devida pelo segurador, quando se verifica o sinistro considerado, independentemente de qualquer exame do dano concreto. A avaliação do dano é, pois, feita de maneira abstrata, e já foram recordadàs as razões que justificam esse modo de avaliação, em materia de ressaricimento do lucro cessante e do beneficio espera'do' e que excluem, nesse caso, a contradição com io conceito 'do ressarcimiento do dano, com a qual se choca, ao contrario, pelo menos normalmente, a avaliação abstrata do dano em materia de dano emergente.

ceira questão) e de Graziani e Azzariti (sobre a segunda), todos na mesma revista:

a) o de prazo inicial da prescrição da ação do segurado contra a responsabilidade civil e do ressegurado;

b) o da subsistencia ou não de uma ação direta ou de um privilegio do terceiro ou do segurado para com a indenização devida pelo segurador (no primeiro caso) ou pelo ressegurado (no segundo caso);

c) o da validade de todas ou algumas das cláusulas graças às quais o segurado (ou o ressegurado) assume (para com o segurador ou o ressegurador) a obrigação (ou o onus) de observar uma determinada conduta para com o terceiro (proibição de transigir; proibição de revelar o seguro; proibição da chamada em garantia; obrigação de conduzir o processo segundo as diretivas do segurador; e assim por diante).

Sobre o seguro de responsabilidade civil, em geral, cfr. o volume de Viterbo, L'assicurazione della responsabilità civile, Milão, Giuffrè, 1936.

Sobre ressseguro, o clássico volume de EmREnberg, Rueckversicherung, e, na doutrina italiana, os de Persico e de Graziani, bem como os estudos de Vivante, Foro It., 1928,, e de Salandra, Assicurazioni, 1934, 1,314. Esses autores, em contraste com a opinião talvez dominante, J. Sraziani, Assicurazioni, 1935, 1,302 encaram no resseguro um novo seguro do mesmo risco já segurado.

Sobre a distinção entre resseguro e cessão do contrato de seguro (ou da massa dos contratos de seguro; a chamada cessão de carteira), cf. os estudos de Vivante e E. FingI na Rivista di diritto commerciale, 1932, 1,656 suscitados pelas disputas jurisprudenciais surgidas por ocasião da falecncia da companhia San Giorgio. 
A) A primeira modalidade de seguros que sob este aspreto merece consideração é a do seguro contra acidentes (infortunios, doenças). E' facil deduzir que esse seguro não considera tanto o dano emergente do sinistrado (despesas de médico, hospital, etc.) (49), quanto o seu lucro cessante e bleneficio esperado, isto é, a sua temporaria ou definitiva, total ou parcial, incapacidade para o trabalho, e que é esse o dano que a indlenização pretende reparar.

A avaliação dessa soma é deixada à vontade das partes nos sieguros privados, justamente porque de outro modo 'ela seria praticamente impossivel, e a avaliação do dano é, portanto, feita abstratamente, numa soma determinada $a$ priori para as varias hípóteses.

Nois seguros sociais, tal soma é geralmente determinada em função dlos ganhos do sinistrado no momento do sinistro. Ela é, pois, limitada ao que póderia dizer-se o lucro cessante em sentido restrito, não compreendendo $\rho$ beneficio esperado, isto é, a melhoria da posição econômica do sinistrado. Esse limite é bem natural, dado o fato de que, no mecanismo do seguro social, os premios e as indenizações devem ser iguais para trabalhadores nas mesmas condições, de maneira que só podem ser considerados os ganhos no momiento do sinistro.

B) Não é difierente, ao meu ver, a situação nos seguros de morte $r(50)$.

(49) Quando separadamente consideradas, tais despesas são indenizadas àparte e a indenização é naturalmente avaliada concretamente, em relação às somas efetivamente gastas.

(50) Refiro-me ao chamado seguro "puro" por motivo de morte, isto é, àquele no qual ao pagamento do premio não corresponde outro direito a não ser o de obter no caso de morte o pagamento de uma indenização.

Na prática italiana esse seguro é pouco conhecido, pois que as formas mais em voga são as chamadas "mistas", que importam no direito à indenização, quer no caso de morte, quer no caso de sobrevivencia depois de um certo lapso de tempo (por exemplo, 20 ou 25 anos)

O seguro "puro" é estipulado para um determinado periodo de tempo (por exemplo, 10 anos) ou é renovavel tacitamente cada ano (cf. Viterbo op. cit.) e o beneficiario tem direito à indenização quando a morte se verifica nesse periodo. 
Para induzir a aproximar as duas formas, concorre, aliás (51), uma observação obvia: a de que o seguro contra infortunios (e o mesmo poderia suceder com o seguro ( contra enfermidades no desenvolvimento da praxe contratual deste ramo) pode compreender tambem a morte em consequencia do infortunio segurado. Em substancia, ao 'passo que no seguro por motivo de morte o risco segurado 'é "a morte" por qualquer motivo ocorrida (52), no seguro contra os infortunios o risco segurado pode ser qualquer consequencia danosa (morte, invalidez temporaria, invalidez permanente, invalidez total ou parcial) que derive do infortunio involuntario ou dum infortunio involuntario devido a determinada causa.

O seguro por motivo de morte corresponide ao conceito do lucro cessante (e do beneficio esperado), justamente porque a morte importa na impossibilidade de realizar os ganhos que, continuando a vida, poderiam ter sido auferidos. E', piois, natural elm cada um o diesejo de evitar essas consequencias de uma morte prematura e assegurar-se de que o proprio patrimonio seja acrescido dos lucros que uma vilda mais longa teria permitido realizar (53). Não so-

São os seguros no caso de morte que tambem mais frequentemente, costumam ser feitos sobre pessoa diversa do estipulante. E' evidente, aliás, que as regras proprias das formas "puras" de seguro constituem a base das regras das formas "mistas"

(51) Prescindindo das observações que possam ser fundadas na classificação adotada por um determinado legislador e que, por isso, não têm valor geral.

(52) Salvo algumas exceções, p. ex. o suicidio voluntario, si bem que a praxe das apólices, em muitos paises, a cobrị o suicidio, quando este ocorre após um certo periodo de eficacia do contrato, considerando que o suicidio, nesta hipótese, não pode ser pre-ordenado.

Geralmente, tambem está compreendido no seguro por motivo de morte, ao contrario do que sucede com o seguro sobre as coisas, quando não seja estipulada uma clausula especial a respeito - 0 risco de guerra, que costuma, todavia, ser excluido por especiais providencias legislativas, depois desta irrompida.

(53) Objeta-se que, na realidade, para quem ganha somente o que gasta (ou ainda menos), a morte prematura não significa a perda de uma possibilidade de aumento patrimonial. Mas, essa consideração pressupõe que não se possa, legitimamente, contar com o aumento dos proprios ganhos.

Ao falar de "lucro cessante" e "beneficio esperado", excluo implicitamente que o seguro por motivo de morte possa reparar o dano 
mente por isso há um rato de previdencia e a previsão de uma eventual necessidade futura no momento da conclusão do contrato, mas há, mais precisamente, um dano como consequencia do sinistro, dano que é sofrido pelo segurado, ou melhor, pelo seu patrimonio (54).

C) E' obvio, todavia, que esse "beneficio esperado" não pode ser atribuido à mesma pessoa sobre cuja vida é feito o seguro, mas necessiariamente a um terceiro. O estipulante pode, por isso, estabelecer diretamente o contrato em favor de um terceiro, imediata ou posteriormente designa'do. E' essa situação aquela da qual partiram os críticos da tese acima sustentada, frizando que o terceiro (beneficiario) podie fazer valer o seu direito à indenização independentemente do proprio interesse à vida do de cujus ou 'de qualquer dano sofrido por morte deste.

A observação é exatíssima: o beneficiario é excluído do seguro quando tenha provocadlo o acidente (55), mas não deve demonstrar interesse pela vida do segurado, nem o seu direito à indenização está subordinado à subsistencia de um dano como consequencia da morte do segura'do.

Esta poide, antes, constituir para ele, até, economicamente, uma vantagem, livrando-o de uma pessoa que antes vivia por sua conta ou deixando-lhe, independentemente do seguro, uma herança mais ou menos pingue. E então, dir-se-á, onde está o dano do beneficiario, ou o 'seu lucro cessante?

$\mathrm{Na}$ verdade, de dano ou lucro cessante, ou beneficio esperado do beneficiario, seria impossivel falar nessas hipóteses!

constituido pelo "gozo dos bens da vida terrena", ao qual se refere, no comentario ao art. 1440 , Clovis BevilacQua.

Esse dano é, com efeito, estritamente pessoal, e nem pode portanto, a meu ver, dizer-se jamais indenizado pelo pagamento de uma soma a pessoa diversa, ao contrario do que sucede com o dano constituido pela falta de incremento patrimonial, que é reparado pelo pagamento destinado àquele ao qual esse incremento patrimonial, quando realizado, teria aproveitado através de uma atribuição do de cujus ou das regras sucessorias.

(54) Dano que, tambem, é sempre do segurado, enquanto momentum mortis vitae tribuitur.

(55) Cf. art.o 79 da lei francêsa de 13 de julho de 1930. 
Mas, o problema se esclarece, recorrendo a uma ordem mais completa die considerações.

0 terceiro beneficiario goza, de fato, de um direito autônomo (56), mas este é, em todo caso, sempre fundado no contrato concluido pelo estipulante: a justificação ido seu direito se encontra na vontade do estipulante e é a ela que deveriamos recorrer parra saber si tal atribuição é a tútulo gratuito - como na generalidade dos casos - ou a título oneroso, como não está excluido (57).

Tanto isso é verdade que é frequente a aplicação à capacidadie do beneficiario das normas qưe regulam a capacidade de adquirir por doação ou sucessão (cf. por exemplo, art. 1.474 do código civil brasileiro).

Tanto isso é verdade que é constante, em todas as leis, a sujeição às normas que concernem à redução das doações das somas gastas pelo estipulante a título de premio.

Si, por um lado, a consideração de que só essas somas sainam do patrimonio do estipulante, ao passo que a indenização constitue um direito proprio do terceiro, permite submeter essas somas (e não a indenização) à redução eventual da doação (58), por outro esssa possibilidade de redução demonstra que, como é obvio, o direito do terceiro encontra não somente a sua flonte no contrato concluido pelo

(56) Tal é a teoria hoje dominante em materia de contrato em favor de terceiros.

57) O que poderá ser relevante em relação à revogabilidade da atribuição (art. ${ }^{\circ} 1473$ do cód. civ. bras.), a qual deve ser admitida em principio, assim como a respeito dos problemas que ora indicaremos sobre a capacidade do beneficiario, a redução da atribuição, etc.. Sobre a eventualidade de um seguro em favor de terceiros a título oneroso, cf. M. Stolfr, L'Assicurazione vita a beneficio di terzi, Milão, 1936.

(58) Cf. cód. it., art.o 453; português, art.o 460; Argentina, lei de 11 de agosto de 1900, n. 3942; para o Brasil, Clovis BeviluacQua, Direito das Obrigações, $4 .^{\circ}$ ed., 1936, pág. 392. Na lei francesa de 13 de julho de 1930 , art..$^{\circ} 68$, a redução das somas pagas a título de premio é admitida somente quando estas sejam manifestamente exageradas em relação aos recursos do estipulante.

Como a indenização constitue um direito proprio do beneficiario, ela não responde pelas dívidas do estipulante (art. ${ }^{\circ} 1475$, cód. bras.). 
estŕpulante, mas em uma atribuição feita por este último ao beneficiario.

Por isso, é bem natural que a lei não faça referencia a uma necessidade do beneficiario, porque isso estaria em contraste com a circunstancia de que o direito do beneficiario encontra aqui justificativa na atribuição por parte do estipulante.

Este, em substancia, através do mecanismo do contrato em favor de terceiro, desempenha uma atribuição em favor do 'beneficiario.

Parece-me, portanto, explicada a razão pela qual, no seguro de vida em caso de morte, se prescinde de uma necessidade do terceiro beneficiario.

Pode-se, ao contrario, afirmar que esse seguro visa reparar um dano ('sob o aspeto do lucro cessante e do beneficio esperado) do estipulante - segurado (59), e é neste, portanto, que deve subsistir o interesse steguravel.

A justificação da indenização se encontra justamente na avaliaçấo abstrata do lucro do qual o patrìmonio 'do estipulante vem a ster privado em consequencia da morte.

A soma correspondente pode, pois, ser 'atribuida pelo estipulante a um terceiro, quer a titulo gratuito, quer a titulo onerosio, e a atribuição pode ter ou dinetamente por objeto essa soma (60), ou ao contrario ser realizada através dum contrato em favor de terceiros (61).

Si essa atribuição não tem lugar, a soma é pertinente a'os herdeiros (62), analogamente ao que sucede, em geral, com o patrimonio do de cujjus.

A hipótese do sieguro em favor de terceiro não está, por isso, em contraste com a considenação do seguro em caso

(59) Voltaremos dentro em pouco à distinção entre estipulante e segurado e aos problemas respectivos.

(60) Por exemplo, por meio de legado tendo por objeto a indenização assegurada.

(61) E é a hipótese normal.

(62) V. art. 1473 do cód. civ. brasileiro. 
de morte, como um seguro do lucno cessante (ou beneficio esperado).

Essa consideração explica, antes, uma praxe constante, cuja justificação não se acharia talvez de outro modo; a tendencia das companhias de seguros de não aceitar contratos de seguro de vida em somas em desproporção manifesta com a posição reconômica do estipulante.

Tal praxe não acha explicação em considerações atinentes à solvabilidade do estipulante (63), mas na consideração de que, alem de um certo limite, a desproporção entre a indenização estipulada e a posição econômica do estipulante faz desaparecer a justificação do seguro e faz nascer a surspeita de 'que o estipulante não tenha um interesse contrario à verificação do sinistro, mas antes seja levado a desejá-lo e provocá-lo.

D) Nos seguros sociais, o direito à indenização não acha sua fonte em uma atribuição por parte do estipulante, mas em uma atribuição por parte da lei, e, por isso, ele é subordinado à subsistencia de um dano do beneficiario. A indenisação é, portanto, atribuida pela lei aos que viviam por conta do segurado ou aos que, si não outro, se podem presumir efetivamente prejudicados pela morte deste.

Por outro lado, como já notamos em relação ao seguro contra acidentes, a indenização é proporcionada aos ganhos do segurado no momento do sinistro, e portanto, considera somente o lucro cesssante em sentido restrito, e não tamblem o beneficio esperado.

E) As considerações precedentes 'permitem afirmar a necessidade de um interesse do estipulante pela vida do segurado. Esse interesse, como se sabe, é geralmente exi-

(63) O pagamento do premio é, com efeito, antecipado, e a falta de pagamento importa, segundo uma praxe constante, na suspensão do contrato.

Aliás, praticamente, as companhias consideram que o pagamento do premio só pode ser voluntario e constitue, não uma obrigação do segurado, mas um onus ao qual está subordinado o seu direito à indenização.

Essa concepção foi aceita na lei francesa de 13 de julho de 1930 sobre os seguros; que não reconhece às companhias o direito de agir para o pagamento do premio do seguro de vida. 
gido nas varias legislações para a validade do seguro de vida (64). Ele é justamente estabelecido para a hipótese em que o seguro seja contratado sobre a vida de pessoa diversa do estipulante (65), mas é obvio observar que, no caso do seguro sobre a propria vida, ele é a priori suposto como subsistente, com uma presunção da qual não se poderia honestamente negar o fundamento.

As considerações precedentes permitem entender porque esse interesse é requerido no estipulante (e não no beneficiario) e superar, portanto, a consideração que parte da referencia ao estipulante e não ao beneficiario do interesse seguravel no seguro de vida, para negar a analogia

(64) Cf. art.o 449, it.,; 549, argentino; art. ${ }^{\circ} 1472$, do cód. civ. brasileiro.

O parágrafo único desse artigo pressupõe justamente a subsistencia do interesse no caso de seguro sobre um ascendente, descendente, irmão ou cônjuge. No comentario de Glovis Beviluacqua a justificação da norma é posta no vinculo afetivo e, portanto, na normal subsistencia dum interesse moral. Mesmo do ponto de vista patrimonial, todavia, subsiste normalmente nesses casos um interesse que justifica a presunção.

0 art.o 109, D. 2063 de 7 de março de 1940 proibe os seguros sobre a vida dos menores de 14 anos.

(65) E a hipótese historicamente originaria do seguro de vida. Esta, com efeito, provavelmente surgiu com um seguro sobre a vida dos escravos.

Um dos casos atuais mais interessantes é o seguro do credor em caso de morte do devedor. Costumam-se contrastar as teses do texto, recordando a jurisprudencia que estabelece que a indenização nessa hipótese é devida, mesmo quando o devedor tenha pago o seu débito. Decisões justas, mas que, ao invés de contrastar, confirmam as nossas teses.

Com efeito, o credor que se segure sobre o proprio devedor, em relação ao pagamento da dívida, não se segura sobre a vida do devedor, mas sobre a solvabilidade deste; é evidente, então, que o pagamento da dívida exclue a possibilidade de reclamar a indenização do seguro.

Ao segurar-se sobre a vida do devedor, o credor quer, na realidade, garantir-se não tanto o pagamento de uma divida, mas uma fonte de lucro, em conformidade justamente ao que sustentamos. 0 caso mais frequente é o de seguro da vida de um bom empregado, - por exemplo, de um técnico especialisado, - por parte do empregador. O empregado fica sempre, naturalmente, com a liberdade de demitirse, mas não é esse o risco contra o qual deseja garantir-se o empregador ao segurar-se sobre a vida do empregado; o empregador está, de fato, nessa hipótese, seguro da fidelidade do empregado, mas teme sua morte, justamente porque o empregado é "insubstituivel", e quer, portanto, com o seguro do empregado no caso de morte, reparar a verda de uma fonte de lucro. 
dessa norma com a doutrina do interesse no seguro sobre as 'coisas.

O interesse do estipulante pode ser, como se sabe, um interesse moral '(66), e tambem essa circunstancia foi adota'da para criticar a possibilidade de aproximar (embora não esquecendo naturalmente as diferenças) a doutrina do interesiste no seguro ide pessoas com a do seguro sobre as colisas.

Esquece-se, ao meu ver, que a possibilidade de uma satisfação pecuniaria como "equivalente" ide uma dor moral não constitue, na realidade, uma peculiaridaide do contrato de seguro, qualquer que seja, nos varios direitos positivos, a solução dada ao problema geral do pretium doloris e da chamada reparação do dano moral (67).

0 interesse, a meu ver, não deve ser reclamado somente no momento da' conclusão do contrato (68).

(66) E dessa consideração, no fundo, que partem as leis que, (como a francêsa de 13 de julho de 1930), se contentam com o consentimento escrito do segurado. Para perceber, todavia, a diferença entre as duas normas, basta ter presente o artigo 550, argentino.

(67) O problema do interesse propõe-se em termos análogos no já citado seguro de nupcias. Tambem este costuma, frequentemente, ser estipulado em favor de um terceiro, que é ao mesmo tempo a beneficiario do seguro e a pessoa em cuja vida se deve verificar o fato segurado (casamento). Em substancia, então, o contrato de seguro em favor de terceiros é o meio técnico para uma constituição de dote e poderemos reportar-nos às normas ora recordadas para o seguro de vida em favor de terceiros, pela medida em que sejam aplicaveis às normas sobre a redução das doações.

Nessas hipóteses, a teoria do interesse (que, como vimos, deve subsistir, quer no estipulante, quer na pessoa em cuja vida deve verificar-se o evento considerado) adquire particular relevo quando considerada com referencia à pessoa em cuja vida deve verificar-se o evento considerado, porque, em substancia, é este que pode provocá-lo... sem ser detido, como na hipótese precedente, pelo espectro da morte.

Tambem aqui, a prática nos demonstra a importancia desse elemento, aceitando somente contratos que, ou pela qualidade ou pela idade do nubente, ou pelo prazo determinado, excluem o que seria de outro modo uma expeculação... especialmente em paises que facilmente admitem o divorcio.

(68) Identico é o principio no seguno sobre as coisas. Por isso deve ser reclamada a subsistencia do interesse no cessionario do contrato de seguro. Cf., explicitamente, art. ${ }^{\circ} 57$, lei francesa de 13 de julho de 1930 . 
Essa interpretação resulta do alcance que, em contraste com a teoria vivanteana, atribuimos à norma, alcance esse que, decidindo de outro modo, viria a dar em nada.

F) O seguro em caso de vida corresponde a um seguro que se pode dizer de velhice, como nos mais conhecidos seguros de sobrevivencia, ou a um seguro para as necessidades que o segurado, sobrevivendo, terá em determinado momento futuro (por exemplo, para custeio dos estudos; no momento da sua maioridade).

No primeiro caso, o estipulante, mais do que a morte, teme negram senectutem (69) e, por isso, estipula um contratio graças ao qual, com o pagamento de uma soma menor que a que seria de outro modo necessaria, asstegura-se um capital ou uma renda para a propria velhice, perdendo (70), reciprocamente, a soma empregada, em caso de morte prematura. Ele não teme a morte, mas a velhice, e é este o fato "danoso", e sem dúvida danoso na apreciação comum.

O dano consiste justamente na menor capacidade de trabalho e, por isso, de ganho, que é, sem dúvida, propria da velhice (71).

A velhice é a eventualidade "desfavoravel" cujas danosas consequencias são reparadas pelo seguro (72).

E' obvio, todavia, o motivo pelo qual o interesse não é concretamente disciplinado, de vez que por um lado seria obviamente ilicito qualquer obstaculo aos esforços do beneficiario para alcançar uma vida mais longa, e, por outro lado, não foi descoberto o elixir-de-longa-vida que permitiria

(69) Raro como seguro privado, o seguro de velhice é, ao contrario, frequente como seguro social.

(70) Considero as formas puras e não as "mistas" (como, por exemplo, o seguro que tem em vista a morte e a sobrevivencia) .

(71) Tambem para quem ganha menos do que gasta, a velhice constitue sempre uma diminuição ulterior da capacidade de trabalho e de ganho.

(72) 0 segurador tem, por sua vez, interesse na "não-sobrevivencia", e isso explica porque ${ }_{\mathrm{r}}$ nessas formas de seguro, se prescinde do exame médico. 
ao segurado, em tais hipóteses, tornar demais gravosa com a sua vontade a prestação do segurador (73).

Tambem nesse caso o seguro pode ser concluido em favor de terceiros; tambem nesse caso o estipulante pode ser pessoa diversa do segurado e podemos ir ter às mesmas considerações precendentemente desenvolvidas acerca do seguro em caso de morte.

Nessas hipóteses, o seguro pode tornar-se um jogo, justamente porque é nesse caso, bem mais que na hipótese do seguro no caso de morte, que o interesse não pode ser eficásmente disciplinado de maneira a servir como criterio de admissibilidade ou não do contrato (74).

Ao passo que nos seguros contra morte é frequente a estipulação do contrato em favor de um terceiro beneficiario, mas não é frequente a dissociação entre estipulante e segurado, nos seguros de sobrevivencia (75) é frequente tambem a estipulação do contrato em favor de um terceiro (76), mas praticamente raro que o beneficiario não seja o proprio segurado.

A praxe de seguros revela, assim, sua sensibilidade, ao excluir as hipóteses nas quais a consideração do interesse seguravel se tornaria evanescente, e indiretamente torna a corroborar o que expusemos sobre o fundamento geral do instituto.

G) Os seguros de sobrevivencia podem, antes que a menor capacidade de trabalho da velhice, visar, como se assinalou, a prover a necessidades excepcionais que costumam verificar-se em alguns momentos da vida ou a despesas extraordinarias previstas para determinadas ocasiões.

(73) Veremos, todavia, dentro em pouco, a importancia desse interesse.

(74) Com efeito, a norma que impõe que o estipulante tenha interesse na sobrevivencia do segurado já não precisa nos seguros em caso de vida, por que nestes (ao contrario do que acontece nos seguros em caso de morte), o lucro é tanto maior quanto mais longa a vida do segurado!

(75) Como nos de nupcias, precedentemente recordados.

(76) E é, muitas vezes, uma atribuição a título gratuito. 
Poderiam ser estipulados visando uma despesa concreta e, portanto, em a soma que concretamente corresponder à despesa (77).

Na pratica esses seguros são estipulados pela avaliação abstrata da despesa em uma soma determinada $a$ priori e que é paga independentemente da demonstração da necessidade.

Mas, tambem aquí, a praxe de seguros nos mostra qual é a justificação do contrato, mesmo quando legislativamente não sancionada. De fato, nos contratos estipulados em favor dos terceiros, é frequente que o pagamento da indenização esteja rigorosamente subordinado à demonstração da necessidade, e a soma é destinada justamente a permitir ao beneficiario fazer o que de outro modo não o poderia.

H) Podemos, assim, afirmar que tambem os seguros de vida' (de morte ou sobrevivencia) se incluem lato sjenisiu no conceito indenitario, no qual somente se pode encontrar a unidade do contrato de seguro, e que estes visam justamente o ressarcimento de uma despesa extraordinaria ou de um lucro cessante e dum beneficio esperado.

Correlatamente, encontramos tambem, nessas modalidades, o reconhecimento legislativo da doutrina do interesse, e notamos que a praxe de seguros visa dar a esta um relevo maior e mais concreto do que tinha na lei.

(77) Por exemplo, para o estudo universitario. Essa possibilidade subsiste mesmo nas hipóteses precedentes: pode-se, pois abstratamente, pensar num seguro em caso de sobrevivencia que comporte, em lugar da renda em dinheiro, o di-eito, por exemplo, de viver gratuitamente em um hotel.

Na pratica, não creio que haja exemplos desses contratos, mas uma autorização nesse sentido, si as minhas informações são exatas, foi dada, há varios anos, pelo departamento italiano de controle, e um projeto análogo fora elaborado, pouco antes da guerra, por um grupo financeiro inglês ligado a sociedades hoteleiras inglesas e suiças. 
Quando (78) tais elementos não entram na disciplina jurídica do contrato, é inutil negar que o contrato cessa de ser um contrato de seguro, toda vez que esses elementos não se encontrem efetivamente no caso concreto (79), muito embora esta falta não dê lugar à falta do direito à indenisação, ao contrario do que acontece nos casos precedentes.

Deparamos até, às vezes, nessas hipóteses, - e isso me parece confírmar a consideração precedente, — a mesma impossibilidade técnica do seguro pois que a falta no beneficiario de um interesse contrario à v'erificação do sinistro, muitas vezes ligada à possibilidade de o provocar legitimamente (80), dificulta a possibilidade de sua previsão no calculo das probabilidades por parte do segurador, e por isso a possibilidade técnica da operação (81).

Achamo-nos, pois, verdadeiramente em face das hipóteses nas quais saimos dos limites do seguro, e a coincidência que assim se encontra nos limites do conceito indenitário e nos da possibilidade técnica do seguro confirma a ordem de idéias aquí defendida.

Todavia, a justificação da consideração dessas hipóteses sob o angulo do seguro se encontra, em substancia, no critério da "normalidade". A lei considera justamente como contratos de seguro todos aqueles que exerçam nor-

(78) Lembro o que escreví sobre os seguros de nupcias e, em geral, sobre os de sobrevivencia.

(79) Consideração análoga é a que, no seguro, só lentamente e com relutancia fez admitir os riscos devidos à culpa do beneficiario e, substancialmente, só àqueles que, mesmo sendo devidos à culpa, são "não-preordenados" Por isso, excluem-se os devidos por dolo. No mesmo conceito inspirou-se a praxe no seguro de responsabilidade civil, e no mesmo conceito se inspiram as cláusulas de suicidio, que tendem a admitir, tambem nesse caso, o pagamento de indenização sómente desde que tenha passado um lapso de tempo tal que exclua que o suicidio pudesse ser preconcebido.

(80) Por exemplo, o casamento, no seguro de nupcias.

Isso torna a demonstrar que, fora do conceito do contrato de indenização, não há possibilidade de distinguir verdadeiramente o seguro do jogo. Já recordei, precedentemente, a insuficiencia reconhecida mesmo por VIvante, da teoria da empresa, para distinguir o seguro do jogo.

(81) Lembro o que escreví sobre os seguros de nupcias ou de sobrevivencia geral e o que citei aquí sobre os expedientes aos quais recorre a praxe contratual. 
malmente a função que assinalamos, ainda que essa função deixe de subsistir num determinado caso concreto e não seja exigida a demonstração de sua existencia.

A praxe contratual vem completando a lei através das clausulas que já recordamos e que visam justamente fazer de modo que o interesse presumido pela lei, exista pois efetivamente na normalidade das hipóteses. $E^{\prime}$ justamente essa subsistencia normal que torna tecnicamente possiveis essas operações e lhes permite desempenhar uma função econômica benéfica.

11 - Nas páginas precedentes, considerei as formas puras de seguro e não as "mistas", nas quais, naturalmente, será mister combinar a disciplina das varias formas puras (82).

E' facil deduzir que os criterios precedentemente desenvolvidos são particularmente evidentes nesses ramos.

A estipulação de um contrato de seguro de vida, nessas hipóteses, alcança o mesmo resultado que seria alcançado através da poupança, mas com uma diferença: evita-se o perigo de se não poder, em consequencia de uma morte prematura, chegar por meio da poupança a acumular a soma desejada. E' para obviar a esse perigo que é estipulado um contrato de seguro, em lugar de se acumular pela poupança uma soma anual equivalente ao premio.

O objetivo do seguro é, portanto, evitar justamente que uma morte prematura impeça que se acumule a soma que se deseja poupar, e, portanto, ressarcir o lucro que, continuando a viver, se poderia realizar. Por isso, nesse ramo de seguro, o beneficiario tem direito a uma soma determinada, quer no caso de morte, quer no caso de sobrevivencia depois de um certo periodo; geralmente na primeira hipótese, a indenização assegurada deve ser paga a um

(82) Os varios ramos de seguros dão lugar, de fato, em suas combinações, a problemas não muito diferentes dos problemas gerais dos chamados contratos mistos. Sobre esses aspectos do problema cf. um estudo de A. Donatr, in Atti Istituto Nazionale delle Assicurazioni, Roma, vol. VI. 
terceiro; na segunda, ao estipulante. A prestação de premio anualmente paga por este ultimo pode, pois, dividir-se em duas frações: uma representa o que o estipulante acumula pela poupança; a outra, o premio de seguro que ele paga para fazer frente ao risco de não poder continuar a poupar em consequencia de uma morte prematura.

Por isso, nesses ramos mistos, mais do que um concurso entre os principios do seguro no caso de sobrevivencia e os do seguro no caso de morte, entrevejo um concurso entre os principios do seguro no caso de morte e os dos contratos de poupança.

Essa constatação justifica a observação comum que, tendo justamente em vista essas modalidades mistas, mais do que as puras, considera o seguro de vida como um contrato de poupança e de capitalização. Essa observação contem um elemento de verdade; nas modalidades mistas concorrem de fato os elementos do contrato de poupança. Ela é, porem, inexata quando aplicada às modalidades puras, quer do seguro no caso de morte, quer do seguro no caso de vida. Basta ter em vista que no seguro puro no caso de morte, o beneficiario não tem nenhum direito no caso de sobrevivencia; no seguro puro no caso de vida, não tem nenhum direito no caso de morte antes do prazo fixado. Por isso, a observação tambem não é rigorosamente exata para as modalidades mistas, porque esquece, por sua vez, a diferença existente entre estas e os contratos de poupança, em virtude justamente da concorrencia do elemento segurador e do direito consequente que tem o beneficiario de obter a indenização no caso de morte, independentemente do montante das somas empregadas, o que não sucede com um contrato de poupança.

12 - Um conceito unitario dos seguros oferece vantagens que me parecem inegaveis na construção do instituto.

A) Assim é em relação ao seguro contra acidentes, o qual de outro modo oscila entre o seguro contra da- 
nos e o de vida, si o contrato de seguro é concentrado sobre essas duas formas concebidas como contrapostas.

Nem o problema é superado quando se classificam os seguros em seguros sobre as coisas e seguros sobre as pessoas, como muitos propõe e como estabelece a lei francesa de 13 de julho de 1930.

Essa classificação pode ser bastante oportuna e talvez seja (como veremos) a preferivel, si entendida como classificação das varias modalidades de seguro em paralelismo com a avaliação do dano por via concreta e por via abstrata, à qual já fizemos referencia.

Mas, essa "classificação" não é mais uma simples "classificação", si os dois grupos de seguro sobre as coisas e sobre as pessoas são concebidos como concentrados num conceito diverso, que seria o indenitario no primeiro e não se saberia qual no segundo.

Desconhecer-se-iam, então, analogias que são lde novo particularmente evidentes, comparando o seguro sobre coisas com o seguro contra acidentes, o qual, sob certos aspectos, se aproxima do seguro sobre coisas, mais do que do seguro de vida.

B) Assim é em relação aos seguros sociais. De fato, achamos nestes os mesmos riscos considerados nos ramos do seguro de pessoas e, ao mesmo tempo, uma disciplina que se aproxima por alguns aspetos - ̀̀ do seguro contra danos, o que é bem explicavel com as considerações que vimos desenvolvendo, mas que não seria explicavel si a diferença do risco considerado devesse importar numa radical diferença de estrutura jurídica.

C) Assim lé em relação ao principio, por toda parte estabelecido, do interesse do estipulante pela vida do segurado, e ainda mais em relação à orientação da praxe de seguros, a esse respeito, e tambem pela diferença entre seguro de morte e seguro de sobrevivencia em relação à sua distinção do jogo. Esse principio e essas diferenças não achariam de outro modo explicação plausivel. 
13 - Recordamos as hipóteses nas quais a avaliação do dano é realizada abstratamente e aquelas nas quais ela é realizada concretamente.

As primeiras hipóteses correspondem aos seguros por danos às pessoas; as segundas aos seguros por danos às coisas.

As primeiras correspondem a seguros por beneficios esperados ou lucros cessantes ou despesas por acontecimentos extraordinarios da vida; as segundas, ao contrario, a um dano emergente em sentido restrito.

a) A avaliação abstrata do dano importa na conhecida consequencia da falta de um limite à soma que as partes fixam como indenização, ao contrario do que sucede na hipótese na qual a avaliação do dano deve ser feita concretamente (83).

Nessa ultima hipótese, a indenização não pode superar o dano concretamente verificado. A soma fixada pelas partes serve para o cálculo dos premios, mas não exclue a possibilidade de ser menor a indenização, si for menor o dano.

b) A soma fixada, quer na hịpótese de avaliação concreta, quer na avaliação abstrata, pode assumir um particular significado, isto é, indicar o limite alem do qual não há ressarcimento com referencia ao sinistro total, de maneira que, no caso de sinistro parcial, se deverá recorrer a um ressarcimento proporcional (84).

c) A avaliação abstrata do dano exclue naturalmente, a possibilidade de afirmar que o seguro seja, no caso concreto, estipulado para um valor superior ao real.

(83) Lembro, todavia, que, excepcionalmente, encontramos tambem nos seguros sobre as coisas a avaliação abstrata do dano: assim, na clausula "valha ou não", onde esta, como por exemplo na interpretação jurisprudencial italiana e francesa, tem esse alcance. Isso confirma a premissa destes estudos.

(84) Esse enunciado da regra pnoporcional, mesmo com referencia à avaliação abstrata do dano e ao seguro sobre pessoas, não é frequente. Mas, a praxe do seguro contra acidentes confirma-lhe a exatidão, porque nessa forma de seguro a indenização é estipulada para o caso de invalidez permanente, total, e a invalidez permanente parcial é justamente ressarcida proporcionalmente. 
Ela permite, tambem (85), a possibilidade de mais seguros para um mesmo risco, cujas indenizações se somem no caso de sinistro.

d)! E' evidente que a avaliação abstrata ou concreta ıdo dano se liga lao problema da possibilidade do segurador subrogar-se ao beneficiario na ação que a este caiba contra o terceiro eventualmente responsavel pelo sinistro (86).

E' obvio que, si a avaliação do dano é feita concretamente e si a indenização atribuida ao segurado corresponde a esse dano, a subrogação deve ter lugar, porque de outro modo o prejudicado viria beneficiar-se por um duplo ressarcimento (do segurador e do terceiro responsavel), ao passo que o segurador, ressarcindo o dano, ressarciria mais do que o dano efetivo, porque o prejudicado teria igualmente direito ao ressarcimento por parte do terceiro responsavel.

Reciprocamente, si a avaliação do dano é feita em uma cifra abstrata, nada se opõe a que o beneficiario conservie o direito para com o terceiro responsavel. Admitida de fato a possibilidade de uma avaliação abstrata, esta não encontra limites quantitativos (87) e, portanto, bem po-

(85) Não, porem, no caso da cláusula "valha ou não", justamente porque mesmo nas ordens jurídicas em que ela é reconhecida como válida, se trata de uma exceção ao principio geral da avaliação concreta do dano no seguro sobre as coisas, a qual só se justifica pela dificil estimação do sinistro marítimo e, portanto, somente nesses limites.

(86) No código de comercio italiano, essa subrogação, admitida no seguro contra danos, é excluida no seguro de vida, o que constitue causa de discussões jurisprudenciais em torno de sua disciplina no seguro contra acidentes. O novo codigo civil italiano (art. ${ }^{\circ}$ 756, livro das obrigações) admite a subrogação no seguro contra acidentes.

(87) Lembro, todavia, o que observei a respeito da praxe de seguros. 
de compreender a indenização, alem do direito ao ressarcimento para com o terceiro responsavel (88).

14 - A unidade do contrato de seguro não exclue, naturalmente, 'a subsistencia dos varios ramos de seguros e a oportunidade, portanto,de classficá-los.

Eles estão sujeitos a normas diversas, das quais algumas foram recordadas no parágrafo precedente.

Com ef eito, não é necessario esclarecer que a afirmada unidade do contrato de seguro não exclue a sua distinção em ramos que, embora ligados a um mesmo conceito fundamental, são inegavelmente distintos e sujeitos a regras diversas, embora compativeis com o conceito fundamental acima assinalado.

A tarefa da classificação consiste, por sua vez, em reagru'par as numerosas modalidades de seguros em poucos grupos, cada um dos quais compreenda ramos juridicamente homogeneos: e, portanto, sujeitos às mesmas regras ou a regras na maior parte idênticas.

E' precisamente essa, a tarefa de todas as classificações.

A classificação talvez mais oportuna é a de seguros sobre as pessoas (89) e seguros sobre as coisas (90).

Não se consegue, assim, uma homogeneidade absoluta dos caracteres proprios de cada grupo; isso, aliás, contrastaria com o que acentuamos precedentemente e com a relatividade sempre propria de qualquer classificação (91).

(88) Esse direito visa o ressarcimento do dano concreto, e a admissibilidade de uma avaliação do dano em abstrato reside justamente no pressuposto da impossibilidade de conseguir um pleno ressarcimento através da avaliação concreta. Por isso acho que nos seguros acidentes, quando falte uma norma legislativa a respeito, a subrogação é excluida ou, ao menos, é licito ás partes convencionar a sua execução, embora sejam eles classificaveis no respectivo direito como um seguro danos em contraposição ao seguro vida.

(89) Inclusive os seguros de vida e contra acidentes.

(90) Cf. sobre o problema, Valeri, Rivista di diritto commerciale, $1930,1,347$, num estudo notavel.

(91) Estas devem, com efeito, traçar um limite nítido, onde na realidade não ha sinão passagens graduais. 
Consegue-se, porem, uma homogeneidade bastante notavel para servir de base á disciplina legislativa (92).

A dieotomia de seguro contra danos e de vida não me parece feliz, hoje (93), com a grande importancia assumida pelo seguro contra acidentes, que nessa dicotomia não encontra sistematização satisfatoria (94).

Igualmente refutavel me pareceria a dicotomia entre seguro de interesses e seguro de pessoas, por varios autores discutida na Alemanha. Essa doutrina parte do conceito, a meu vêr, inexacto, de que o objeto do seguro seja, a rigor, o interesse seguravel, e da inexata afirmação de que a doutrina do interesse seja propria somente do seguro sobre as coisas.

Presumimos, ao contrario, ter demonstrado nestas páginas a unidade substancial do contrato de seguro, não obstante as peculiaridades proprias dos seus varios ramos.

(92) Substancialmente, portanto, parece-me digna de ser seguida a classificação adotada na lei francesa de 13 de julho de 1930, preparada, de resto, pelo civilista francês talvez mais ilustre destes ultimos anos, Capitant.

$\mathrm{Na}$ lei francesa, o seguro de responsabilidade civil constitue um capitulo aparte. Querendo estabelecer uma dicotomia, ele deveria ser considerado, antes, como um seguro sobre coisas, mas os seus caracteres específicos aconselham, em todo caso, uma disciplina em separado.

(93) Com efeito, ela provém da doutrina e da legislação do século XIX, quando o seguro contra acidentes era praticamente desconhecido, o que contribue, aliás, para explicar as orientações doutrinarias daquela época. O novo codigo civil italiano mantém porem a dicotomia dos seguros danos e de vida.

(94) Na Italia é, pois, constante, por parte da doutrina, a inclusão do seguro contra acidentes no seguro contra danos, ao passo que a jurisprudencia, ao contrario, no inicio do sec. $\mathrm{XX}$ considerou - seguro contra acidentes como um seguro de vida; depois, sob a influencia da doutrina, como um seguro contra danos; e agora, de novo, como um seguro de vida. Cf. minha nota citada em Assicurazioni, 1937. O novo codigo civil italiano aceita a tese da doutrina e classifica o seguro contra acidentes como um seguro contra danos. 